\title{
INTERTEMPORAL STATE BUDGETING
}

\author{
Bruce Baker \\ Daniel Besendorfer \\ Laurence J. Kotlikoff \\ Working Paper 9067 \\ http://www.nber.org/papers/w9067
NATIONAL BUREAU OF ECONOMIC RESEARCH
1050 Massachusetts Avenue
Cambridge, MA 02138 \\ July 2002
}

The authors gratefully acknowledge the support of the Pioneer Institute, the German National Merit Foundation, Boston University, and the U.S. Department of Commerce. The paper benefited greatly from the comments and suggestions of James Stergios. We thank Jonathan Skinner and Felicitie Bell for providing essential data. The views expressed herein are those of the authors and not necessarily those of the National Bureau of Economic Research.

(C) 2002 by Bruce Baker, Daniel Besendorfer and Laurence J. Kotlikoff. All rights reserved. Short sections of text, not to exceed two paragraphs, may be quoted without explicit permission provided that full credit, including (C) notice, is given to the source. 
Intertemporal State Budgeting

Bruce Baker, Daniel Besendorfer and Laurence J. Kotlikoff

NBER Working Paper No. 9067

July 2002

JEL No. H7

\begin{abstract}
$\underline{\text { ABSTRACT }}$
This study presents intertemporal budgeting as of 1999 for all 50 U.S.states. Intertemporal state budgeting compares the present value of a state 's projected receipts with the present value of its projected expenditures (exclusive of interest payments)plus the current value of its net debt (liabilities minus assets). Our projections start with the 1999 U.S.Census Bureau 's State Government Finances survey of receipts,expenditures,and debt.We group these highly detailed data into a framework that is consistent with the National Income and Product Account accounts. The 1999 Census data are the latest available. To project total receipts and expenditures for years beyond 1999,we first form average 1999 receipts and expenditures by age and sex using relative age-and sex-specific receipts and expenditure profiles. We estimate these profiles the Current Population Survey and the Consumer Expenditure Survey. Next we grow these averages using an assumed growth rate in labor productivity. Finally,year-and state-specific age-sex population estimates are multiplied by projected average receipts and expenditures by age and sex in that year to form that year 's total projected state-specific receipts and expenditures. We form our year-age-sex-and state-specific population projections using the 2001 Social Security Administration 's projection of the total U.S.population by age and sex in conjunction with the 1995 Census projections on state-specific age-sex population shares. Our base-case results use a 3 percent real discount rate and assume a 1.5 percent real productivity growth rate. They show a great range of state intertemporal imbalances. When measured as a share of (scaled by)the present value of projected expenditures, imbalances range from positive 48 percent in Alaska to negative 19 percent in Vermont. These and other findings proved to be very robust to changes in productivity and discount rates as well as changes in demographic assumptions. State official liabilities are not good proxies for their intertemporal imbalances.Indeed, the correlation between scaled state intertemporal imbalances and gross state debt scaled by state income is essentially zero.The corresponding correlation based on net state debt is negative. Given this, it's not surprising that we find very little correspondence between the ranking of the states based on their intertemporal budget imbalances and the credit ratings published by either Moody 's or Standard and Poor's. Our user-friendly program for calculating intertemporal state budget imbalances (the difference between a)the present value of expenditures plus net debt and b)the present value of receipts)is written in Excel and is available for download upon request.Users can input their own discount and growth rates. They also can modify the demographic projections.In addition, the program contains historical Census expenditure and receipts data.Based on these data or their own knowledge of current trends in their state 's public finances,users can override all or some of the program 's short-term receipts and expenditures projections.Users can also have the program begin its projections starting in a year they specify.
\end{abstract}

Bruce Baker

U.S. Department of Commerce

Daniel Besendorfer

Boston University and Universitat Freiburg

Laurence J. Kotlikoff

Boston University and NBER 


\section{Introduction}

In the Fall of 2000, the State of Massachusetts announced that the Big Dig project - the nation's largest highway construction project - would cost roughly 10 percent more than previously projected. Given that the total costs had been projected at $\$ 14$ billion, a 10 percent overrun was no minor matter. The announcement led to Congressional hearings, the firing of the top state official overseeing the project, and the establishment of a new management team. A few weeks after the announcement, the citizens of Massachusetts went to the polls to vote, among other things, on a referendum to cut the state's income tax rate by roughly 10 percent.

The referendum passed, but in voting for or against the referendum, one thing was clear. None of the voters had any real understanding about the degree to which the Big Dig cost overrun would seriously undermine the state's long-term finances. The reason is that the State of Massachusetts, like all other states in the country, does no long-term fiscal analysis or, for that matter, any long-term fiscal planning. Hence, there was no way of comparing the large one-time additional Big Dig costs with, for example, the present value of the state's future expenditures. Consequently, none of the Massachusetts voters were in a position to know whether the state could really afford the tax cut.

This paper seeks to rectify this situation. It presents an intertemporal budgeting for 2001 for all 50 U.S. states. Intertemporal state budgeting compares the present value of a state's projected receipts with the present value of its projected expenditures (exclusive of interest payments) plus the current value of its net debt (liabilities minus assets). Armed with a state intertemporal budget, policymakers can answer a host of questions that would otherwise be very hard to entertain. These include: How large is the state's intertemporal budget imbalance? What immediate and permanent percentage 
tax hikes or spending cuts are needed to eliminate the state's intertemporal budget imbalance? And, are state credit ratings correlated with state intertemporal imbalances?

Our projections start with the 1999 U.S. Census Bureau's State Government Finances survey of receipts, expenditures, and debt. We group these highly detailed data into a framework that is consistent with the National Income and Product Account accounts. The 1999 Census data are the latest available. To project total receipts and expenditures for years beyond 1999, we first form average 1999 receipts and expenditures by age and sex using relative age- and sex-specific receipts and expenditure profiles. We estimate these profiles using data culled from the Current Population (CPS) and Consumer Expenditure (CEX) surveys. Next we grow these averages using an assumed growth rate of labor productivity. Finally, year- and state-specific age-sex population estimates are multiplied by projected average receipts and expenditures by age and sex in that year to form that year's total projected state-specific receipts and expenditures. We form our year-age-sex- and state-specific population projections using the 2001 Social Security Administration's projection of the total U.S. population by age and sex in conjunction with the 1995 Census projections on state-specific age-sex population shares. ${ }^{1}$

Our Excel program (written in VBA for Excel) is user-friendly and available for download upon request. Users can input their own discount and growth rates. They can also modify the demographic projections. In addition, the program contains historical Census expenditure and receipts data. Based on these data or their own knowledge of current trends in their state's public finances, users can override all or some of the

\footnotetext{
${ }^{1}$ The Social Security Administration data also include pre-2001 population counts. We use data from 1999 onward.
} 
program's short-term receipts and expenditures projections. Users can also choose to have the program begin its projections only after a year they specify. Finally, users can choose the base year for their intertemporal budget analysis. For example, they can determine the intertemporal imbalance that prevailed in 1999 just as easily as the imbalance prevailing in 2001 .

Our base-case results assume a 3 percent real discount rate and a 1.5 percent real productivity growth rate. They show a great variation across states in their intertemporal imbalances measured as a percent of the present value of projected expenditures. Imbalances range from 48 percent in Alaska to -19 percent in Vermont! These and other findings proved to be very robust to changes in productivity and discount rates as well as changes in demographic assumptions.

Remarkably, we find no relationship between a state's long-term fiscal problems and its general obligation bond rating. This is not surprising given that there is a) essentially no correlation between states' scaled intertemporal imbalances and their ratios of gross debt to state income and b) a negative correlation between states' scaled intertemporal imbalances and their ratios of net debt to state income.

The next section, II, lays out our projection methodology. Section III presents our data. Section IV describes our findings and considers their sensitivity to assumed discount rates, growth rates, and demographic assumptions. Section V compares state intertemporal budget gaps with Standard \& Poor's and Moody's state general obligation bond ratings, and Section VI compares them with official debt figures. Section VII summarizes and concludes the paper. 


\section{Methodology}

Our projection of each state's total receipts and expenditures in each post-1999 year begins with a calculation of average expenditures and receipts by age and sex in 1999, broken down by type of receipt and expenditure. We illustrate this calculation for expenditures. The calculation for receipts is identical.

\section{Calculating Relative Expenditure and Receipt Profiles}

Let $E_{i, s, b}$ stand for the value of a total expenditure of type $i$ in state $s$ in base year $b$, and form

$$
E_{i, s, b}=\bar{e}_{i, m, 40, s, b} \sum_{a=0}^{110}\left(R_{i, m, a} P_{m, a, s, b}+R_{i, f, a} P_{f, a, s, b}\right),
$$

where $i$ and $a$ denote expenditure type and age and $m$ and $f$ refer to male and female. The term $\bar{e}_{i, m, s, 40, b}$ stands for the average expenditure of type $i$ on 40 year-old males in state $s$ in year $b . R_{i, j, a}$ stands for the ratio of a) average expenditures of type $i$ made on age group $a$ of $\operatorname{sex} j$ to $b$ ) the average expenditures of type $i$ made on 40-year-old males. ${ }^{2}$ Note that our age-sex relative expenditure and receipt profiles are not indexed by year or by state. Instead, we use the latest available nationwide profiles and assume they will maintain their current shape through time and that they are applicable for all states. ${ }^{3}$ The term $P_{, j, a, s, b}$ stands for the number of people of $\operatorname{sex} j$ who are age $a$ in state $s$ in the base year $b$.

Given the values of the relative expenditure profile, $R_{i, j, a}$ and the population counts $P_{, j, a, s, b}$, equation (1) is used to solve for $\overline{\mathrm{e}}_{\mathrm{i}, \mathrm{m}, 40, \mathrm{~s}, \mathrm{~b}}$. Once this value is known, we can

\footnotetext{
${ }^{2}$ We modify this procedure in the case of state workers' pension income. Specifically, we calculate the relative pension income profit using a 60 -year-old male, rather than a 40 -year-old male as our reference group.

${ }_{3}^{3}$ Data are available to calculate state-specific profiles, but their use may add more noise than signal to our calculations because the profiles would be calculated with significantly fewer observations.
} 
calculate year $b$ average expenditures of type $i$ for all other age groups $a$ and $\operatorname{sex} j$ in state $s, \bar{e}_{i, j, a, s, b}$, from

$$
\bar{e}_{i, j, a, s, b}=\bar{e}_{i, m, 40, s, b} R_{i, j, a} \quad \text { for } \mathrm{j}=\mathrm{m}, \mathrm{f} .
$$

Total projected expenditures of type $i$ in year $t$ in state $s, E_{i, s, t}$, can now be written as:

$$
E_{i, s, t}=\sum_{a=0}^{110}\left[\bar{e}_{i, m, a, s, b}(1+g)^{t-b} P_{m, a, s, t}+\bar{e}_{i, f, a, s, b}(1+g)^{t-b} P_{f, a, s, t}\right],
$$

where $g$ is the constant growth rate of labor productivity.

Not all expenditures and receipts have an age-sex pattern. For example, there seems no way to distinguish the level of police and fire protection by age and sex. Hence, for such public goods, we assume that the relative distribution profiles are flat (the $R_{i, m, a}$ and $R_{i, f, a}$ values equal 1 for all ages and sexes). This translates into assuming that the per capita level of such expenditures grows with labor productivity, so that the total level of these expenditures grows with population plus productivity.

In the case of state educational expenditures, we form a) expenditures per child in elementary and secondary school and b) expenditures per child in higher education. These amounts are assumed to grow with labor productivity. The total level of those expenditures in each future year is projected to equal these productivity-adjusted per capita amounts multiplied by the number of children in the particular education group in the year in question.

\section{Calculating a State's Intertemporal Budget Imbalance}

If we let $T_{i, s, t}$ stand for total government receipts of type $i$ in state $\mathrm{s}$ in year $t$, the state's intertemporal budget imbalance $\left(\mathrm{GAP}_{\mathrm{s}}\right)$ is given by 


$$
\mathrm{GAP}_{\mathrm{s}}=\sum_{t=0}^{\infty}\left[E_{i, s, t}-T_{i, s, t}\right] /(1+r)^{t}+D_{s},
$$

where $D_{s}$ stands for net debt of state $s$ at time $b$, defined as the value of all state liabilities minus all state assets, and $r$ is the discount rate.

The program starts by projecting population counts by age and sex and state based on an assumed population scenario. Next it distributes 1999 budgetary aggregates using equation (1). It then uses assumed productivity growth rates to determine average expenditures and taxes of various kinds by age and sex and future years. These amounts are then multiplied by the age- and sex-specific population counts to determine total values of the different receipts and expenditures in each future year. The final step uses equation (3) to form the present value budget imbalance.

To compare results across states, we divide the absolute value of each state's intertemporal budget imbalance by either the present value of its expenditures or the present value of its receipts. The resulting percentages indicate what immediate and permanent percentage cut in expenditures or percentage increase in receipts is needed to achieve present value budget balance. We also show the immediate and permanent percentage cuts in specific expenditures and increases in specific taxes that would, by themselves, balance the state's intertemporal budget.

\section{The Data}

This section first describes our population data and projections. It then turns to the Census classifications and our use of the CPS and CEX surveys to generate relative receipt and expenditure profiles by age and sex. 


\section{Population Projections}

Our population projections are based in part on the intermediate (II) projection of population by age and sex used by the Social Security Administration (SSA) in their 2001 OASDI Trustees Report. ${ }^{4}$ This projection provides population estimates through 2080 . To form values for the $P_{, j, a, t}$, we simply multiply SSA national population counts by each state's age- and sex-specific population shares in year $t$.

These state-specific population shares are created using a 1995 Census projection by Campbell (1996), which forecasts population totals for each state by age and sex through 2025..$^{5}$ Day (1996) describes fertility, mortality, and international migration assumptions used by the Census. Unfortunately, the Census has not updated these state forecasts since 1995, although it may do so in the near future. ${ }^{6}$

In our baseline calculations we form the average annual growth rate of age-, sex-, and state-specific population shares between 2021-2025 and grow the 2025 age- and sexspecific state population shares for the years 2026 through 2030 based on this rate. After 2030, we assume the shares remain constant. The year to which we extend trend growth in the age- and sex-specific state population shares can be modified by the user in running the program.

As a test for the validity of the calculated shares, we compared the resulting state population totals with state population estimates provided by the U.S. Bureau of the Census for the years 1997 through 1999. The state population totals as well as the national population total are consistently approximately 4 percent higher in our

\footnotetext{
${ }^{4}$ Report available at http://www.ssa.gov/OACT/TR/TR01/index.html. Chapter V provides an exact description of all assumptions that have been made for the three scenarios.

${ }_{6}^{5}$ Projections are also available based on race and Hispanic origin.

${ }^{6}$ Unfortunately, the Census did not retain the state-specific net migration data and other data that we would need to update their projections on our own.
} 
calculations than in the Census' estimates. This difference occurs mainly due to the fact that, unlike the Social Security Administration estimates, the Census estimates exclude U.S. citizens, including members of the military, residing abroad.

For the purpose of our study, however, this is not overly problematic. A higher state population, as long as it is consistent over all states, lowers our estimate of per capita receipts and expenditures, but once we multiply these values by our higher than Census population estimates, we still end up with an unbiased projection of total expenditures and receipts in each year.

Table 1 shows how the state total populations and age-compositions are projected to evolve between 1999 and 2050. The trends are very clear. The share of population age 18 and under shrinks in every state from, on average, 27 percent to, on average, 22 percent over the next fifty years. At the same time the average state share of population of age 65 and older rise from 12 percent to 22 percent. In 1999 there was no state whose youth outnumbered its elderly. In 205029 states will have more oldsters than youngsters. This aging of the states' residents and voters will likely have important implications for the types and levels of expenditures and receipts selected by state governments.

If the elderly's population share is rising and that of the youth is declining, what happens to overall dependency ratios? The answer is they rise. The share of the population that is in its working years - the middle aged - shrinks in every state.

\section{Census Data on State Government Finances}

Our state budget data come from the U.S. Bureau of the Census 1999 State Government Finances survey. These data are aggregated to roughly accord with NIPA 
accounting conventions. A perfect correspondence is not possible because certain data needed for that purpose is not available on a state-by-state basis, e.g. depreciation. However, the data do conform to the NIPA concept of net lending, which is a cash measure of the government's borrowing requirement. Table 2 shows the budget categories used in the study.

Overall the resulting NIPA-like figures differ somewhat from the original Census data ordering since NIPA conventions not only aggregate the much more detailed Census data but also consolidate them. In the NIPA's, some items like health expenditures have charges netted against spending, while the Census data show the transactions on a gross basis. It is important to note that both the Census data and the resulting NIPA-like estimates include transactions for all state funds, not just "general funds".

\section{Relative Age-Sex Receipt and Expenditure Profiles}

The values for relative age-sex receipt and expenditures profiles come from the Current Population Survey (CPS), the Current Expenditure Survey (CEX), and the Health Care Financing Agency (HCFA) respectively. The CPS was used to form relative profiles for state income taxes, state workers retirement contributions, state pension plan retirement benefits, and disability payments to state workers. The CEX was used to form relative profiles for motor vehicle licenses, property taxes, other taxes (mostly licenses), general sales taxes, and eight separate excise taxes. HCFA data, supplied by Jonathan Skinner, were used to create Medicaid relative expenditure profiles, which were used for all welfare-related aggregates. The profile of educational expenditures is a step function calculated by dividing expenditures on children in elementary school, secondary school, 
and higher education. All other budgetary items are assumed to be equally distributed by age and sex.

Figure 1 presents graphs of all non-flat distribution profiles used in this study. Table 2 lists all budget categories for which we have assumed a flat age-sex profile making the projected per capita levels of these receipts or expenditures the same in a given year regardless of age or sex.

The CEX data used to form average annual expenditures by age and sex were taken from the 1999 survey. CPS data are extracted from the Annual Demographic Survey March 2000 Supplement. To smooth the original data we usually apply secondorder polynomials. The only exceptions are the welfare profile, the retirement-benefits profile, and the unemployment insurance contributions profile, for which we used a step function and five-year moving averages, respectively. The reason for this different treatment is the special shapes of these profiles, which would be missed by smoothing with second-order polynomials.

Table 4 shows population shares by state of the young and old as well as the shares of total state expenditures spent on these age groups. Expenditures exclude interest payments but include retirement benefits and other state transfer payments. The first thing to note is that while youngsters (those under 19) represent, on average, 27 percent of state populations, on average they receive only 13 percent of spending. For oldsters, the story is the reverse. Their population share averages 12 percent across states, but their expenditure share averages 31 percent.

The share of total expenditures spent on youngsters is less than the share spent on oldsters in all states except Alaska and Hawaii. The explanation for Alaska is its 
remarkably small -6 percent - share of elderly. For Hawaii the explanation is twofold. First, Hawaii has quite high elementary educational expenditures per student. Second. Hawaii spends relatively little on the health sector, which is used much more extensively by the elderly. At the other extreme are Ohio and Oregon. Both states spend 8 percent of all their expenditures on the young, but Ohio spends 38 percent and Oregon 37 percent on the old. Clearly, given current spending patterns, aging means one thing in Alaska and Hawaii and something quite different in Ohio and Oregon.

\section{State Intertemporal Budget Imbalances}

For our baseline scenario we assumed an annual per capita productivity growth rate of 1.5 percent and an annual real discount rate of 3 percent. We also extended the trend in state-specific age-sex population shares from 2025 through 2030. Beyond 2030 we assumed that each state's share of the total population of a given age and sex equals its 2030 share. ${ }^{7}$ All discounting is done back to the base year, 1999. Absolute dollar figures are presented in 1999 dollars.

Figure 2 and columns 2 and 5 in Table 5 provide an overview of the base-case results. It shows state imbalances measured as percentages of both the present values of expenditures and receipts. Three-fifths of the states have a positive intertemporal budget imbalance. Alaska and North Dakota have the largest imbalances, equivalent to 48 percent and 42 percent of the present values of their expenditures and 77 percent and 80 percent of the present values of their receipts. Wyoming is the next worse off fiscally

\footnotetext{
${ }^{7}$ One has to keep in mind that this procedure might lead to inconsistent results for the U.S. as a closed system since it is obvious that for example, not all states' shares of total U.S. population can grow at the same time. For our purpose, however, this method can be chosen, since it is not the goal of this study to conduct an investigation of the complete U.S. but a comparative measure of its single states.
} 
speaking. It has an imbalance of 20 percent when measured relative to expenditures and 23 percent when measured relative to receipts. Another eight states, including the heavily populated states of California and New York, have imbalances ranging from 10 to 16 percent, when measured relative to expenditures. Vermont has the smallest imbalance, indeed a negative imbalance, equal to -19 percent of the present value of expenditures and -15 percent of the present value of receipts. Note that the expenditures and receipts rankings of the states' long-term fiscal shortfalls are identical for all but four states. However, for some states, the two measures are quite different in magnitude.

The differences across states in the sizes of their imbalances are driven, in part, by short-run fiscal outcomes that are being projected, given our methodology, to continue into the future. Alaska and North Dakota are two cases in point. Alaska experienced a 40 percent decline in total tax and non-tax receipts in 1999 compared with 1998. North Dakota experienced a 26 percent increase in total welfare expenditures across the two years. These two examples suggest the need to improve the current analysis by taking into account the temporary nature of certain fiscal policies in forming long-term fiscal projections. On the other hand, they clarify that there are very real problems facing both Alaska and North Dakota.

\section{Intertemporal Budget Imbalances in 1990}

The above results indicate the intertemporal imbalances that states face if they maintain in the future their current age- and sex-specific pattern of expenditures and taxes, except for an adjustment for productivity growth. Of course, these spending and tax patterns are likely to change over time, especially for states with large imbalances. 
Were we to know exactly what the future would bring, we could determine the extent to which actual, as opposed, to projected future fiscal policy is in intertemporal balance.

This, of course, is impossible. However, it is possible to go back in time and use the spending and taxes that actually materialized, at least from that date in the past, to the present. We did this in preparing Figure 3. Specifically, we chose 1990 as the base year (i.e., we discounted back to 1990), used actual data from 1990 to 1999 and projected data from 2000 on using the method described above. Table 6 compares the results for 1990 with those for 1999. Although the imbalance rankings of several states differs somewhat across the two periods (e.g., Iowa's rank of 37 fell to 33 and Massachusetts' rank rose from 36 to 39), the overall rank correlation between imbalances across the two years is .996. For all but six states, the intertemporal imbalances declined over the decade.

\section{Achieving Fiscal Sustainability}

What do the 1999 findings imply for achieving sustainable fiscal policies in the different states? As mentioned, the imbalance measures also indicate actions that could be taken to achieve fiscal sustainability. Thus, the State of Alaska could halve all its expenditures or raise all its receipts by four-fifths on a permanent basis to achieve longterm fiscal sustainability. Either option represents a wrenching change in policy. On the other hand, Vermont could reduce its receipts by 15 percent or raise its expenditures by 19 percent on a permanent basis.

We also considered the reductions in particular types of expenditures and increases in particular types of receipts that could achieve fiscal sustainability. Certain of 
these policies are clearly infeasible. For instance, Alaska would have to decrease its educational expenses by roughly 400 percent to get its long-term finances in order.

For other states, there is a range of feasible options. For example, Indiana could either lower its educational expenditures by 4.16 percent or decrease its health expenditures by 1.45 percent to restore sustainability. Another option for this state would be to raise individual income taxes by 1.68 percent or increase its sales taxes by 1.35 percent.

Interestingly, there is a very substantial variation across states that have similar imbalances in their menus of potential fiscal adjustments. Take, for example, Hawaii and Maryland. Both states have imbalances totaling between 8 and 9 percent of the present values of their expenditures. But Hawaii's income tax base is proportionately smaller than that of Maryland, and achieving fiscal sustainability through an increase in state income taxes would require a 35.9 percent tax hike in Hawaii, but only a 20.6 percent increase in Maryland.

What does this long-term fiscal analysis tell us about Massachusetts' ability to afford cost overruns in the Big Dig project? The 10 percent rise in the costs of Massachusetts' Big Dig project equals $\$ 1.4$ billion. Given that in our baseline scenario Massachusetts has an absolute present value imbalance of $\$ 146.5$ billion dollars, this corresponds to an increase of roughly 1 percent in the state's long-term fiscal problem. To meet these costs, Massachusetts could cut its expenditures, on a permanent basis, by .12 percent or to raise its receipts, on a permanent basis, by .09 percent. Hence, the Big Dig cost overrun turns out to be a rather small problem in the wider scheme of things. 


\section{Sensitivity Analysis}

The ranking of the states based on their imbalances turns out to be relatively insensitive to changes in assumptions. Consider first the productivity growth rate, which, in our baseline case, equals 1.5 percent. As shown in Tables 7 and 8, lowering that rate to 1 percent or raising it to 2 percent leads to fairly similar cross-state patterns of fiscal imbalances when measured either as a share of the present value of spending or as a share of the present value of receipts. The sizes of the imbalances are also generally within a percentage point or two of their base-case values. Higher productivity growth worsens the states' fiscal positions because it increases the absolute size of the gaps in each future year between receipts and expenditures. The tables also show little sensitivity of the results to extending the growth trends of age-sex state population shares for a decade rather than for just five years. In all cases, the differences in scaled imbalances is less than half of a percentage point.

The choice of discount rate makes a bigger difference to the results, with higher discount rates lowering the measured imbalance. Take, for example, NY's base-case imbalance of 12.9 percent of spending. The base case assumes a 3 percent real rate of

discount. Using a 4 percent discount rate lowers the measure of the imbalance to 11.3 percent. The difference between the two figures is 12.4 percent, indicating that the rate at which a state can borrow can make a material impact on the sustainability of its policy.

\section{State Credit Ratings}

How do our findings compare with state general obligation bond ratings by Standard and Poor's (S\&P's) and Moody's, which purport to be based on a state's long- 
term fiscal condition. ${ }^{8}$ In making this comparison, we used 1999 ratings for the 41 out of the 50 states that are rated by both agencies. These states and their ratings are listed in Table 9. We transformed the letter-based rating systems into a cardinal one, ending up with a scale ranging from 21 for AAA to 1 for $\mathrm{C}$. The resulting numerical credit ratings for both companies range from 14.4 to 21 , with an average of 19.2 for both agencies and standard deviations of 1.46 for S\&P's and 1.38 for Moody's.

The ratings of the two agencies are very similar. Indeed, the correlation coefficient between the two sets of ratings is .92 . In contrast, the correlation between the values of our relative imbalance measures and either firm's credit ratings is very low. When the imbalance is measured relative to the present value of receipts, its correlation is -.14 with the S\&P ratings and -.15 with the Moody's ratings. Note that a correlation is what one would expect since a higher imbalance should be associated with a lower credit rating. For imbalances measured relative to expenditures the correlations are -.16 and -.19 , respectively. We also used the ratings and imbalance measures to rank the states on the size of their fiscal problems. The rank correlation coefficients from this analysis are also remarkably low -- .21 for S\&P's and .23 for Moody's. Finally, we considered whether the 1990 credit rating rankings are more highly correlated with the 1990 ranking of states based on intertemporal imbalances scaled by expenditures. The answer is no. The rank correlation is .24 for S\&P's and .13 for Moody's. ${ }^{9}$

\footnotetext{
${ }^{8}$ Compare Standard and Poor's (2000) for instance.

${ }^{9}$ Only 38 states were ranked by both agencies in 1990. Also Moody's rating system was less detailed in 1990 than in 1999.
} 
Apparently, the demographic factors included in our analysis are being neglected by the credit rating agencies. This is particularly surprising given that these agencies seem to understand that long-term demographics are important to fiscal sustainability. For example, in a recently published study by Standard and Poor's for the 15 member countries of the European Union, Kraemer and Marchand (2002) conclude that "The sovereign credit ratings of highly rated European Union (EU-15) members could begin to come under downward pressure by end of the decade if no progress is made in further fiscal consolidation and structural reform to counter the financial challenges of aging societies." ${ }^{10}$

State credit ratings make a material difference to the price states pay for credit and their ability to use credit to deal with unexpected shocks to expenditures or receipts. ${ }^{11}$ For 1999, the yield spread between an average AAA rated general obligation bond and one rated AA was .08 and .11 percentage points for maturities of 1 year and 30 years, respectively. The corresponding spreads between an AAA rating and an A rating are .25 and .27 percentage points. And the two AAA-BBB spreads are .45 and .52 percentage points. For certain maturities, the yield spreads were even higher -- .67 percentage points between a BBB rating and a AAA for 13 years maturity.

Based on our findings, Alaska, Oregon, Ohio, and Maryland are paying much less than they should for credit, while Connecticut, Arkansas, West Virginia, and Louisiana are paying much more than they should. Take Maryland and Louisiana, for example. While Maryland's 1991 scaled intertemporal imbalances were roughly three times larger

\footnotetext{
${ }^{10}$ These authors predict a remarkable increase in ratings that are below the current lowest rating (the ' $\mathrm{A}$ ' rating on Greece) to four countries by 2023 and even to seven countries by the early 2030s.

${ }^{11}$ See Asdrubaldi,. Sorensen, and Yosha (1996).
} 
than those of Louisiana, Maryland's 1999 S\&P credit rating was AAA, while Louisiana's was A-. Another telling comparison is between Connecticut and Arkansas. Both had 1999 S\&P credit ratings of AA even though Connecticut's imbalances were close to negative 10 percent and those of Arkansas were close to positive ten percent.

\section{Is Official Debt a Good Proxy for a State's Intertemporal Budget Imbalance?}

In addition to bearing little relationship to credit ratings, our intertemporal imbalances are only weakly correlated with a traditional measure of fiscal sustainability, namely state government debt. The correlation between absolute total gross debt and the absolute intertemporal imbalance is .67. However, the correlation with total net debt, which is presumably most relevant to a state's fiscal status, is -.59 . We also measured the

correlations between a) the scaled imbalance and b) gross or net debt scaled by total annual state personal income of 1999 as measured by the Bureau of Economic Analysis (BEA). The correlation of the gross debt measure with our imbalance measure is .10 when imbalances are scaled relative to the present value of receipts and .09 when they are scaled relative to the present value of expenditures. As before we found much lower correlations with the net debt measured as a share of state income. The correlation is -.45 when imbalances are scaled by receipts and -.38 when they are scaled by expenditures. The correlations between state gross debt scaled by state income and credit ratings are, as expected, negative: - .39 for S\&P's and -.38 for Moody's.

Another interesting result concerns the budget deficit in 1999. The strong influence of the base year choice is reflected in a .83 correlation between the absolute deficit and the absolute intertemporal imbalance. Even when we use the imbalance 
relative to present value of expenditures we still observe a correlation of .34 . The absolute deficit is also negatively correlated with credit ratings, with a correlation of -.14 for S\&P's and -.25 for Moody's.

\section{Conclusions}

This study compares the long-term fiscal positions of the 50 U.S. states. The study combines long-term demographic projections with state budget data and relative age-sex receipt and expenditure profiles to measure each state's present value budget imbalance. Our findings indicate a great deal of heterogeneity across states in the magnitude of their long-term fiscal problems. Three fifths of the states have unsustainable policies. Of these, one third need to make major adjustments to rectify their fiscal circumstances. This conclusion turns out to be very robust to changes in assumed productivity growth rates, demographic assumptions, and discount rates.

Remarkably, our ranking of states based on their fiscal imbalances bears no relationship to the state credit ratings of either Moody's or Standard and Poor's. If our results are to be believed, many states are being forced to borrow at higher rates than they should, while others are being permitted to borrow at lower rates than is justified by their fiscal conditions. There is also only a weak relationship between states' intertemporal imbalances and their ratios of debt-to-income.

Our work is at an early stage. Refined projections of both short- and long-term fiscal flows that take into account the business cycle, soon-to-be released Census projections of state populations by age and sex, and likely changes over time in the agesex profiles of different state government receipts and expenditures are needed to more 
accurately measure state intertemporal imbalances. Still, even at this early stage, measuring states' long-term fiscal affairs appears to offer a much better perspective on the sustainability of their fiscal policies than does the very short-term budget analysis now being employed. 


\section{References}

Asdrubaldi, Pierfederico, Bent E. Sorensen, and Oved Yosha, "Channels of interstate risk sharing: United States 1963-1990", The Quarterly Journal of Economics, November 1996, 1081-1110.

Campbell, P. R., "Population Projections for States by Age, Sex, Race, and Hispanic Origin: 1995 to 2025", U.S. Bureau of the Census, 1996.

Day, J. C., "Population Projections of the United States by Age, Sex, Race, and Hispanic Origin: 1995 to 2050", U.S. Bureau of the Census, Current Population Reports, P251130, Washington, D.C.: U.S. Government Printing Office, 1996.

Kraemer, M. and L. Marchand, "Western Europe Past Its Prime - Sovereign Rating Perspectives in the Context of Ageing Populations", Standard and Poor's, Ratings Direct, January 9, 2002.

Standard and Poor's (Edt.), Standard and Poor's Public Finance Criteria 2000, New York: McGraw Hill, 2000. 


\section{Figure 1}

\section{Relative Receipts and Expenditure Profiles}
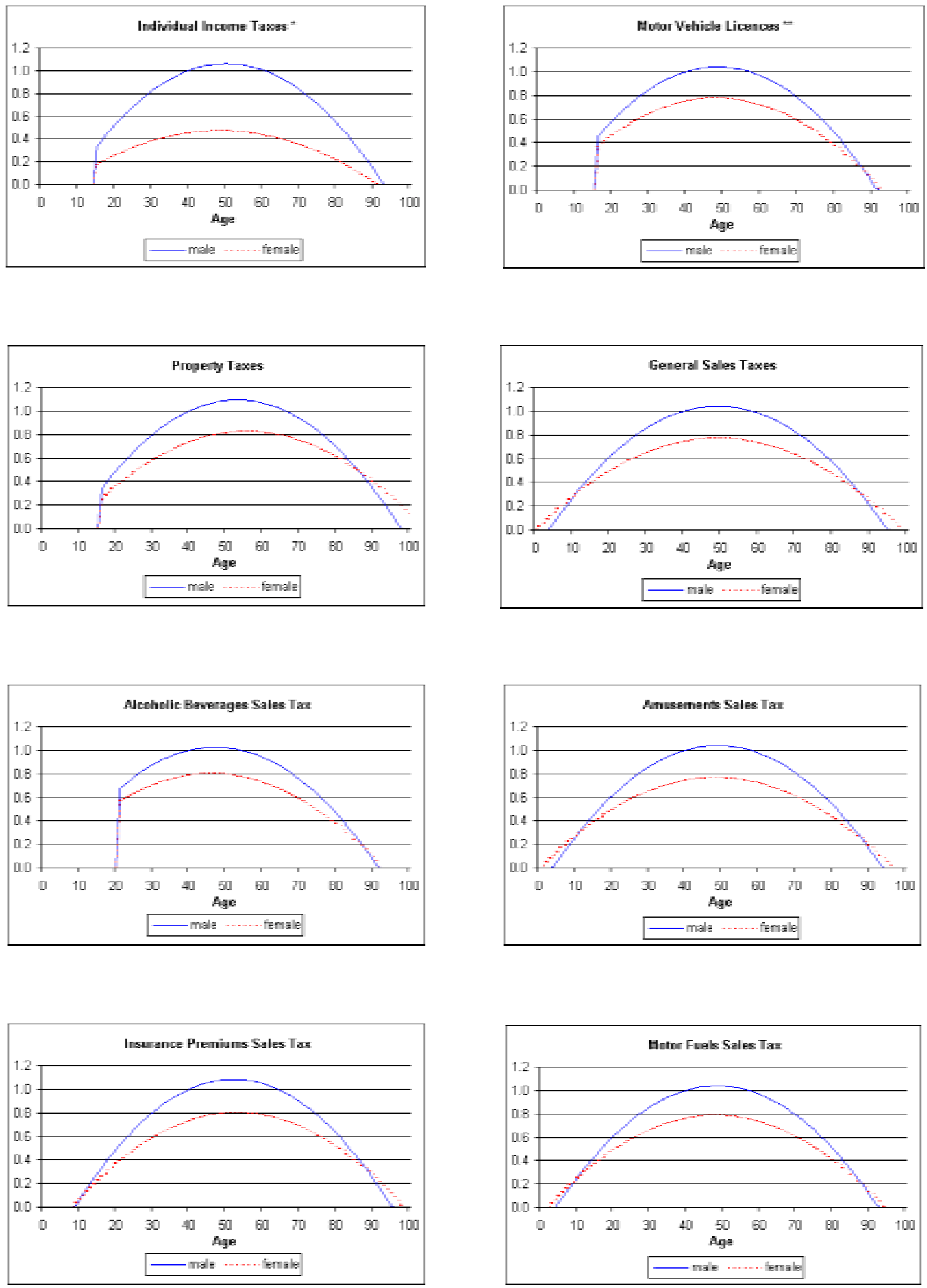

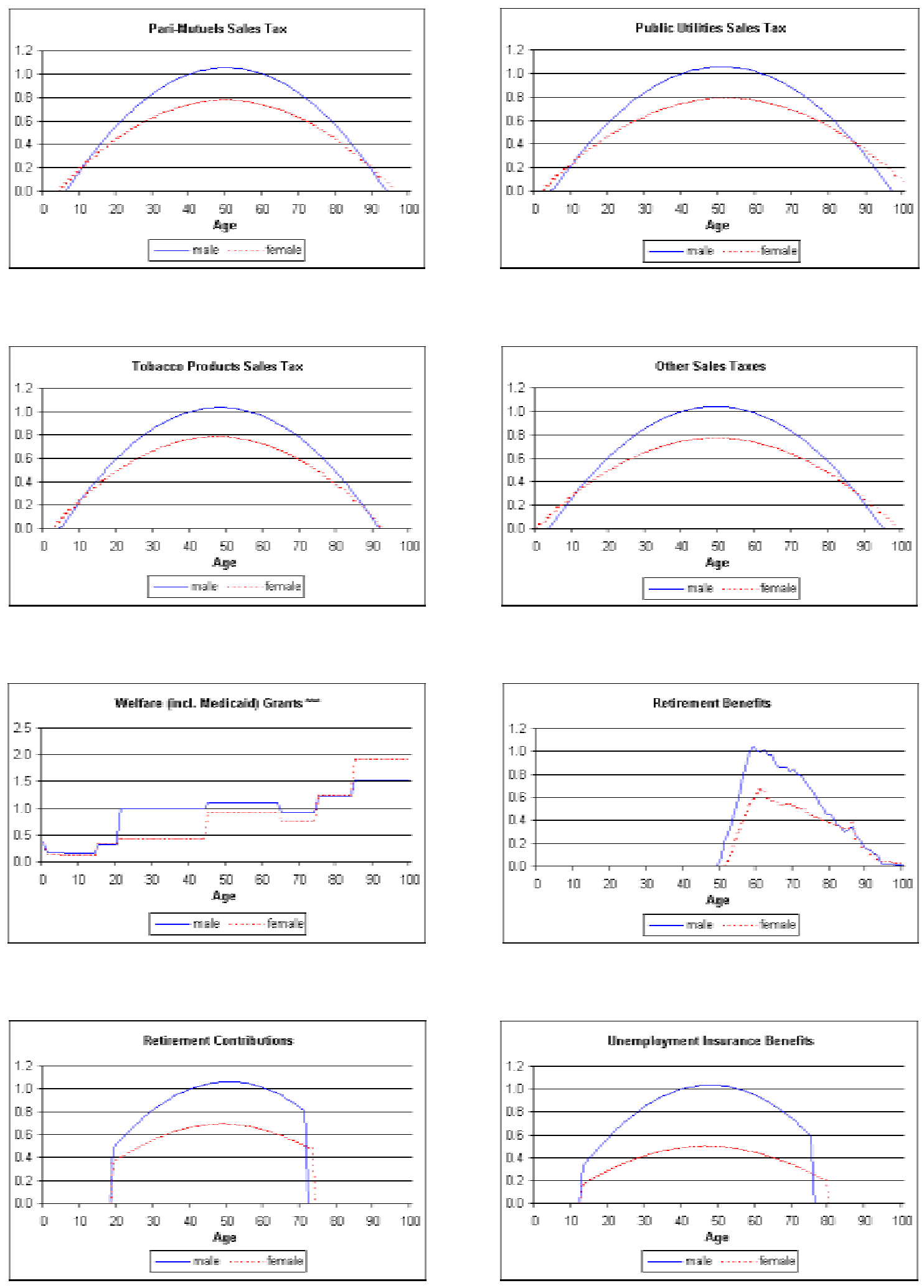


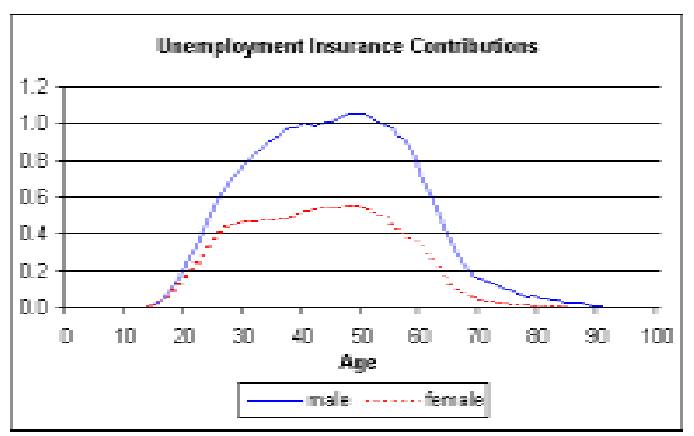

* Individual income tax profile also used for distributions of disability expenditures

** $\quad$ Motor vehicle licenses profile also used for distribution of other taxes (mostly licenses).

*** Welfare grants profile also used for distribution of health expenditures, vendor medical payments, and welfare expenditures. 
Figure 2

State Intertemporal Budget Imbalances in 1999

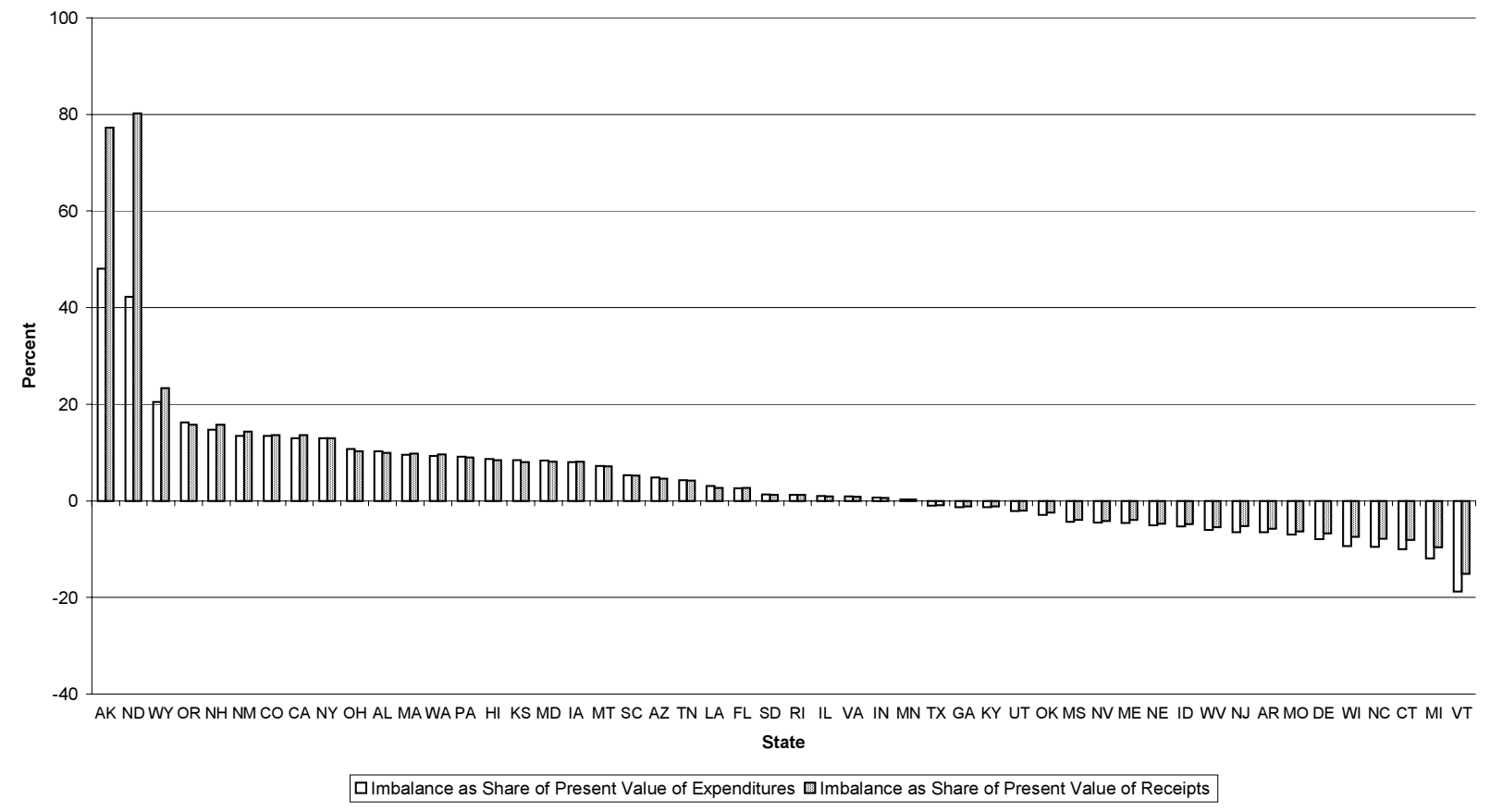


Figure 3

State Intertemporal Budget Imbalances in 1990

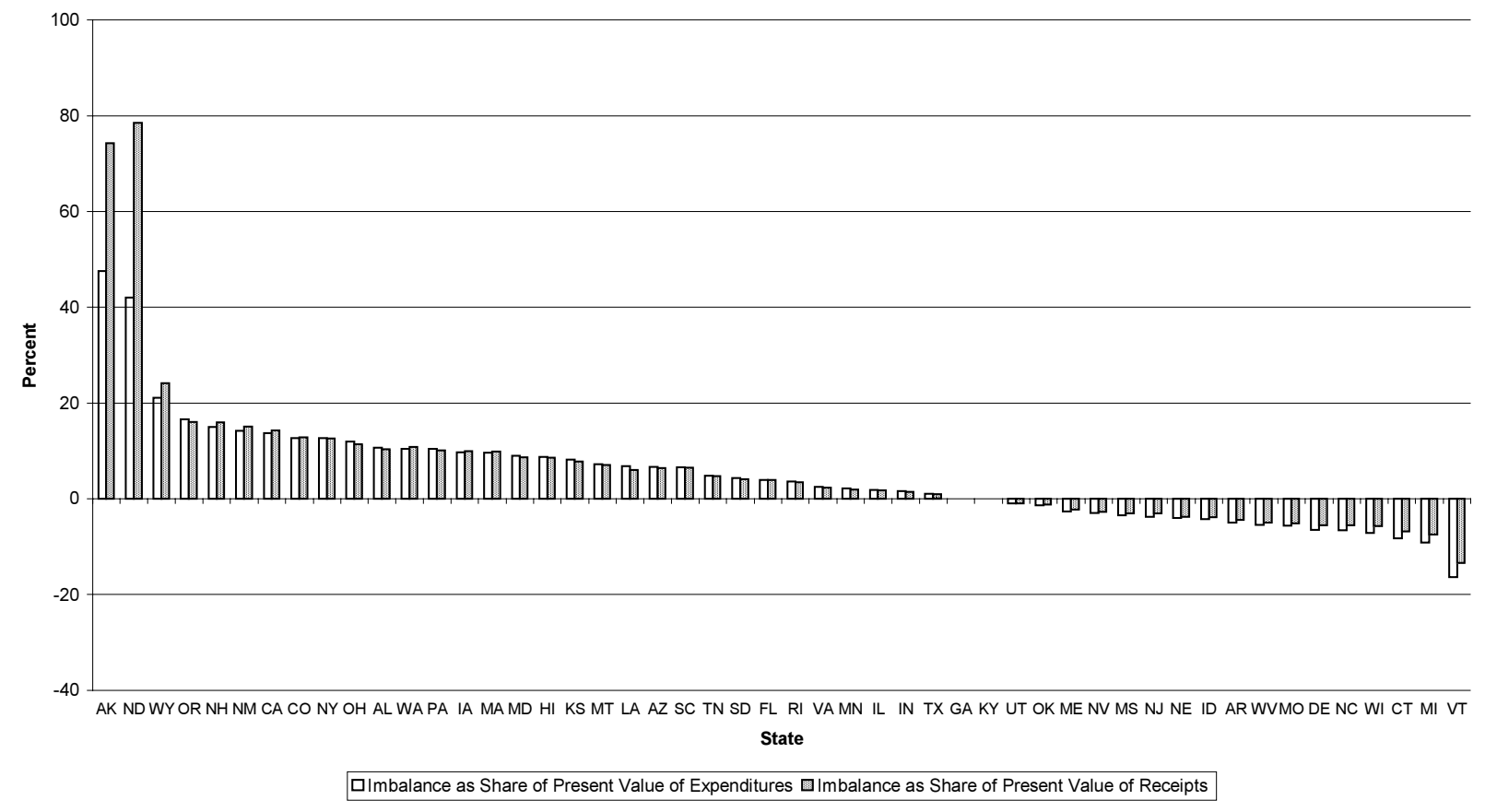




\section{Table 1}

\section{State Population Projections}

\begin{tabular}{|c|c|c|c|c|c|c|}
\hline State & $\begin{array}{l}\text { Population } \\
\text { in } 1999\end{array}$ & $\begin{array}{l}\text { Population } \\
\text { in } 2050\end{array}$ & $\begin{array}{l}\text { Share of } 18 \\
\text { and Under } \\
\text { in } 1999\end{array}$ & $\begin{array}{l}\text { Share of } 18 \\
\text { and Under } \\
\text { in } 2050\end{array}$ & $\begin{array}{c}\text { Share of } 65 \\
\text { and Over } \\
\text { in } 1999\end{array}$ & $\begin{array}{c}\text { Share of } 65 \\
\text { and Over } \\
\text { in } 2050\end{array}$ \\
\hline $\mathrm{AK}$ & 670927 & 993046 & .32 & .30 & .06 & .11 \\
\hline $\mathrm{AL}$ & 4586516 & 5827379 & .26 & .20 & .13 & .22 \\
\hline AR & 2705597 & 3406933 & .27 & .19 & .14 & .26 \\
\hline $\mathrm{AZ}$ & 4876756 & 7249814 & .29 & .23 & .13 & .24 \\
\hline $\mathrm{CA}$ & 33619448 & 56943841 & .30 & .28 & .10 & .14 \\
\hline $\mathrm{CO}$ & 4256286 & 5851915 & .27 & .21 & .11 & .23 \\
\hline $\mathrm{CT}$ & 3412554 & 4212827 & .26 & .22 & .14 & .20 \\
\hline DE & 788767 & 956413 & .26 & .21 & .12 & .21 \\
\hline FL & 15602016 & 23833595 & .25 & .18 & .18 & .29 \\
\hline GA & 8061853 & 11038420 & .28 & .22 & .10 & .19 \\
\hline $\mathrm{HI}$ & 1293270 & 2109723 & .28 & .25 & .12 & .18 \\
\hline IA & 3002511 & 3371604 & .26 & .20 & .15 & .25 \\
\hline ID & 1365186 & 1956863 & .30 & .22 & .11 & .24 \\
\hline IL & 12490615 & 14933014 & .28 & .24 & .12 & .18 \\
\hline IN & 6239474 & 7227467 & .27 & .21 & .12 & .21 \\
\hline $\mathrm{KS}$ & 2753756 & 3470818 & .28 & .23 & .13 & .22 \\
\hline KY & 4126834 & 4762074 & .26 & .19 & .13 & .23 \\
\hline LA & 4581314 & 5713714 & .29 & .23 & .12 & .20 \\
\hline MA & 6421504 & 7725009 & .26 & .21 & .14 & .20 \\
\hline MD & 5442565 & 7032734 & .27 & .22 & .11 & .18 \\
\hline ME & 1304827 & 1585496 & .25 & .19 & .13 & .24 \\
\hline MI & 10041851 & 11080589 & .27 & .22 & .12 & .20 \\
\hline MN & 4979903 & 6147436 & .28 & .21 & .12 & .23 \\
\hline MO & 5716425 & 6937492 & .27 & .21 & .13 & .22 \\
\hline MS & 2904341 & 3474298 & .29 & .22 & .12 & .21 \\
\hline MT & 971911 & 1259486 & .27 & .20 & .13 & .28 \\
\hline $\mathrm{NC}$ & 7973142 & 10489615 & .26 & .19 & .12 & .24 \\
\hline ND & 683921 & 816338 & .27 & .22 & .15 & .26 \\
\hline NE & 1759665 & 2151615 & .28 & .22 & .14 & .24 \\
\hline $\mathrm{NH}$ & 1259161 & 1606031 & .27 & .20 & .11 & .21 \\
\hline NJ & 8458247 & 10747844 & .26 & .22 & .13 & .19 \\
\hline NM & 1900258 & 2975224 & .30 & .26 & .11 & .18 \\
\hline NV & 1884031 & 2595936 & .26 & .19 & .11 & .23 \\
\hline NY & 18863971 & 22036094 & .27 & .23 & .13 & .18 \\
\hline $\mathrm{OH}$ & 11735599 & 12939606 & .27 & .21 & .13 & .22 \\
\hline OK & 3484431 & 4566304 & .27 & .21 & .14 & .24 \\
\hline OR & 3481088 & 4958532 & .26 & .19 & .14 & .27 \\
\hline PA & 12654797 & 14015489 & .25 & .21 & .15 & .23 \\
\hline RI & 1035099 & 1283325 & .26 & .22 & .15 & .21 \\
\hline $\mathrm{SC}$ & 3973569 & 5205194 & .27 & .20 & .12 & .23 \\
\hline
\end{tabular}




\begin{tabular}{ccccccc}
\hline \hline State & $\begin{array}{c}\text { Population } \\
\text { in 1999 }\end{array}$ & $\begin{array}{c}\text { Population } \\
\text { in 2050 }\end{array}$ & $\begin{array}{c}\text { Share of 18 } \\
\text { and Under } \\
\text { in 1999 }\end{array}$ & $\begin{array}{c}\text { Share of 18 } \\
\text { and Under } \\
\text { in 2050 }\end{array}$ & $\begin{array}{c}\text { Share of 65 } \\
\text { and Over } \\
\text { in 1999 }\end{array}$ & $\begin{array}{c}\text { Share of 65 } \\
\text { and Over } \\
\text { in 2050 }\end{array}$ \\
\hline SD & 798786 & 962564 & .29 & .22 & .14 & .25 \\
TN & 5803674 & 7433537 & .26 & .20 & .12 & .22 \\
TX & 20648775 & 30786326 & .30 & .26 & .10 & .18 \\
UT & 2246190 & 3222979 & .35 & .27 & .08 & .20 \\
VA & 7205927 & 9517227 & .26 & .21 & .11 & .20 \\
VT & 635406 & 751066 & .26 & .20 & .12 & .23 \\
WA & 6008285 & 8904257 & .27 & .21 & .11 & .23 \\
WI & 5498460 & 6513296 & .27 & .21 & .13 & .23 \\
WV & 1909950 & 2032099 & .24 & .17 & .15 & .27 \\
WY & 536405 & 783707 & .28 & .23 & .11 & .24 \\
\hline \hline
\end{tabular}


Table 2

State Budget Categories

\begin{tabular}{|c|c|}
\hline Receipts & Expenditures \\
\hline Individual income taxes & Executive and legislative \\
\hline Motor vehicle licenses & Tax collection and financial \\
\hline Property taxes & Net interest paid (baseyear only) \\
\hline Other taxes (mostly licences) & Other general public service \\
\hline Nontaxes & Police \\
\hline Fines and forfeits & Fire \\
\hline Donations & Law courts \\
\hline Other & Prisons \\
\hline Corporate profits taxes & General economic \\
\hline Indirect business taxes and nontaxes & Agriculture \\
\hline Sales taxes & Energy \\
\hline General & Natural resources \\
\hline Alcoholic beverages & Transportation \\
\hline Amusements & Highways \\
\hline Insurance premiums & Air transportation \\
\hline Motor Fuels & Water transportation \\
\hline Pari-mutuels & Transit and railroad \\
\hline Public utilities & Other economic \\
\hline Tobacco products & Liquor stores \\
\hline Other & Lotteries \\
\hline Property taxes & Misc. comm. act \\
\hline Motor vehicle licenses & Parking \\
\hline Other & Misc. insurance trust \\
\hline Nontaxes & Water \\
\hline Rents and royalties & Sewer \\
\hline Special assessments & Sanitation \\
\hline Fines & Other \\
\hline Donations & Education \\
\hline Tobacco settlement & Elementary and secondary education \\
\hline Other & Higher education \\
\hline Contributions for social insurance & Libraries \\
\hline Intergovernmental Transfers & Education, nec. \\
\hline Transportation & Health \\
\hline Air transportation & Hospitals \\
\hline Highways & Vendor medical payments \\
\hline Other transportation & Recreation and culture \\
\hline Health and hospitals & Disability \\
\hline Education (head start, Indian, etc.) & Welfare \\
\hline \multicolumn{2}{|l|}{ Employment } \\
\hline \multicolumn{2}{|l|}{ Housing } \\
\hline \multicolumn{2}{|l|}{ Welfare (includes Medicaid) } \\
\hline \multicolumn{2}{|l|}{ Utilities } \\
\hline \multicolumn{2}{|l|}{ Other } \\
\hline Estate and gift taxes & \\
\hline
\end{tabular}




\begin{tabular}{ll}
\hline \multicolumn{1}{c}{ Retirement } & \multicolumn{1}{c}{ Unemployment Insurance } \\
\hline Receipts & Receipts \\
Benefits & Benefits \\
Interest (baseyear only) & Interest (baseyear only) \\
\hline \multicolumn{1}{c}{ Cash and Securities } & \\
\hline Insurance trusts & Debt \\
Retirement systems & Full faith and credit \\
Unemployment systems & Nonguaranteed \\
Workers' comp. & Short term \\
Other insurance trusts & \\
Other than insurance & \\
\hline \hline
\end{tabular}


Table 3

\section{Budgetary Items Assumed to Have Flat Distribution Profiles}

\begin{tabular}{ll}
\hline \hline \multicolumn{1}{c}{ Receipts } & \\
\hline Fines and forfeits & Expenditures \\
Donations & Executive and legislative \\
Other nontaxes & Tax collection and financial \\
Corporate profit taxes & Other general public services \\
Property taxes & Police \\
Motor vehicle licences (business) & Fire \\
Other business taxes & Law courts \\
Rents and royalties & Prisons \\
Special assessments & General economic \\
Fines & Agriculture \\
Donations & Energy \\
Tobacco settlement & Natural resources \\
Other business nontaxes & Highways \\
Contributions for social insurance & Air transportation \\
Air transportation grants & Water transportation \\
Highway grants & Transit and railroad \\
Other transportation grants & Liquor stores \\
Health and hospital grants & Lotteries \\
Education grants (head start, & Misc. comm. act \\
indian, agegroups 3 and 4) & Parking \\
Employment grants & Misc. insurance trust \\
Housing grants & Water \\
Utilities grants & Sewer \\
Other grants & Sanitation \\
Estate and gift taxes & Other economic \\
& Elementary and secondary education \\
& (agegroups 5-18 only) \\
& Higher education \\
& (agegroups 19-22 only) \\
\hline \hline & Libraries \\
& Education, nec. \\
& Hospitals \\
& Recreation and culture \\
\hline & \\
\hline &
\end{tabular}


Table 4

The Age-Composition of State Spending in 1999

\begin{tabular}{|c|c|c|c|c|}
\hline State & $\begin{array}{c}\text { Share of } \\
\text { Population } \\
18 \text { and } \\
\text { Under }\end{array}$ & $\begin{array}{c}\text { Share of } \\
\text { Population } \\
65 \text { and } \\
\text { Over }\end{array}$ & $\begin{array}{c}\text { Share of } \\
\text { Total } \\
\text { Expenditures } \\
\text { Spent on } \\
\text { those } 18 \text { and } \\
\text { Under }\end{array}$ & $\begin{array}{c}\text { Share of } \\
\text { Total } \\
\text { Expenditures } \\
\text { Spent on } \\
\text { those } 65 \text { and } \\
\text { Over }\end{array}$ \\
\hline $\mathrm{AK}$ & .32 & .06 & .26 & .19 \\
\hline $\mathrm{AL}$ & .26 & .13 & .09 & .34 \\
\hline $\mathrm{AR}$ & .27 & .14 & .11 & .32 \\
\hline $\mathrm{AZ}$ & .29 & .13 & .14 & .28 \\
\hline $\mathrm{CA}$ & .30 & .10 & .13 & .30 \\
\hline $\mathrm{CO}$ & .27 & .11 & .12 & .30 \\
\hline $\mathrm{CT}$ & .26 & .14 & .13 & .31 \\
\hline $\mathrm{DE}$ & .26 & .12 & .13 & .29 \\
\hline FL & .25 & .18 & .11 & .35 \\
\hline GA & .28 & .10 & .12 & .30 \\
\hline HI & .28 & .12 & .31 & .24 \\
\hline IA & .26 & .15 & .12 & .31 \\
\hline ID & .30 & .11 & .13 & .29 \\
\hline IL & .28 & .12 & .11 & .36 \\
\hline IN & .27 & .12 & .11 & .32 \\
\hline $\mathrm{KS}$ & .28 & .13 & .12 & .29 \\
\hline KY & .26 & .13 & .11 & .33 \\
\hline LA & .29 & .12 & .12 & .33 \\
\hline MA & .26 & .14 & .12 & .34 \\
\hline MD & .27 & .11 & .11 & .32 \\
\hline $\mathrm{ME}$ & .25 & .13 & .10 & .37 \\
\hline MI & .27 & .12 & .09 & .33 \\
\hline $\mathrm{MN}$ & .28 & .12 & .10 & .34 \\
\hline MO & .27 & .13 & .12 & .34 \\
\hline MS & .29 & .12 & .13 & .32 \\
\hline MT & .27 & .13 & .14 & .29 \\
\hline $\mathrm{NC}$ & .26 & .12 & .13 & .30 \\
\hline ND & .27 & .15 & .18 & .32 \\
\hline $\mathrm{NE}$ & .28 & .14 & .12 & .30 \\
\hline $\mathrm{NH}$ & .27 & .11 & .11 & .36 \\
\hline NJ & .26 & .13 & .16 & .31 \\
\hline NM & .30 & .11 & .14 & .30 \\
\hline NV & .26 & .11 & .11 & .27 \\
\hline NY & .27 & .13 & .11 & .35 \\
\hline $\mathrm{OH}$ & .27 & .13 & .08 & .38 \\
\hline OK & .27 & .14 & .11 & .32 \\
\hline OR & .26 & .14 & .08 & .37 \\
\hline
\end{tabular}




\begin{tabular}{ccccc}
\hline \hline State & $\begin{array}{c}\text { Share of } \\
\text { Population } \\
\mathbf{1 8} \text { and } \\
\text { Under }\end{array}$ & $\begin{array}{c}\text { Share of } \\
\text { Population } \\
\mathbf{6 5} \text { and } \\
\text { Over }\end{array}$ & $\begin{array}{c}\text { Share of } \\
\text { Total } \\
\text { Expenditures } \\
\text { Spent on } \\
\text { those 18 and } \\
\text { Under }\end{array}$ & $\begin{array}{c}\text { Share of } \\
\text { Total } \\
\text { Expenditures } \\
\text { Spent on } \\
\text { those 65 and } \\
\text { Over }\end{array}$ \\
\hline PA & .25 & .15 & .11 & .35 \\
RI & .26 & .15 & .13 & .34 \\
SC & .27 & .12 & .11 & .34 \\
SD & .29 & .14 & .14 & .32 \\
TN & .26 & .12 & .10 & .33 \\
TX & .30 & .10 & .13 & .31 \\
UT & .35 & .08 & .15 & .25 \\
VA & .26 & .11 & .13 & .28 \\
VT & .26 & .12 & .13 & .31 \\
WA & .27 & .11 & .10 & .32 \\
WI & .27 & .13 & .11 & .33 \\
WV & .24 & .15 & .10 & .33 \\
WY & .28 & .11 & .16 & .25 \\
\hline \hline
\end{tabular}


Table 5

Alternative Fiscal Adjustments that Would Achieve Present Value Budget Balance

(percentage cuts in expenditures or increases in receipts)

\begin{tabular}{|c|c|c|c|c|c|c|}
\hline State & $\begin{array}{c}\text { Total } \\
\text { Expenditures }\end{array}$ & Education & Health & $\begin{array}{c}\text { Total } \\
\text { Receipts }\end{array}$ & $\begin{array}{l}\text { Income } \\
\text { Taxes }\end{array}$ & $\begin{array}{l}\text { Sales } \\
\text { Taxes }\end{array}$ \\
\hline $\mathrm{AK}$ & 48.12 & 415.26 & 230.30 & 77.24 & --* & 1437.74 \\
\hline AL & 10.22 & 63.23 & 20.82 & 9.95 & 43.54 & 26.80 \\
\hline $\mathrm{AR}$ & -6.49 & -42.82 & -13.84 & -5.79 & -22.86 & -14.99 \\
\hline $\mathrm{AZ}$ & 4.77 & 31.90 & 15.98 & 4.55 & 14.74 & 7.27 \\
\hline CA & 12.96 & 86.44 & 30.94 & 13.56 & 24.30 & 26.35 \\
\hline $\mathrm{CO}$ & 13.48 & 99.73 & 35.65 & 13.59 & 28.90 & 38.80 \\
\hline $\mathrm{CT}$ & -9.99 & -105.22 & -23.82 & -8.10 & -24.71 & -18.67 \\
\hline $\mathrm{DE}$ & -7.94 & -48.42 & -21.79 & -6.75 & -19.82 & -56.34 \\
\hline FL & 2.58 & 28.64 & 5.02 & 2.62 & -- & 3.63 \\
\hline GA & -1.28 & -6.96 & -2.83 & -1.15 & -2.86 & -3.07 \\
\hline HI & 8.63 & 27.61 & 27.54 & 8.44 & 35.86 & 19.67 \\
\hline IA & 7.96 & 48.38 & 21.39 & 8.11 & 25.54 & 18.77 \\
\hline ID & -5.32 & -47.83 & -13.99 & -4.82 & -14.22 & -12.09 \\
\hline IL & 0.96 & 8.48 & 2.29 & 0.90 & 2.81 & 2.05 \\
\hline IN & 0.68 & 4.16 & 1.45 & 0.63 & 1.68 & 1.35 \\
\hline $\mathrm{KS}$ & 8.41 & 46.72 & 22.12 & 8.03 & 20.68 & 15.91 \\
\hline $\mathrm{KY}$ & -1.29 & -11.01 & -2.79 & -1.18 & -4.51 & -3.42 \\
\hline LA & 3.02 & 22.49 & 6.77 & 2.66 & 16.37 & 6.88 \\
\hline MA & 9.56 & 105.08 & 19.67 & 9.80 & 18.90 & 32.52 \\
\hline MD & 8.32 & 69.69 & 20.44 & 8.06 & 20.56 & 21.47 \\
\hline ME & -4.59 & -56.91 & -9.21 & -4.00 & -14.25 & -12.81 \\
\hline MI & -11.95 & -71.91 & -32.34 & -9.65 & -25.44 & -19.25 \\
\hline $\mathrm{MN}$ & 0.27 & 1.86 & 0.60 & 0.24 & 0.52 & 0.53 \\
\hline MO & -7.00 & -68.54 & -14.50 & -6.34 & -18.36 & -17.27 \\
\hline MS & -4.35 & -34.64 & -8.63 & -3.94 & -23.07 & -7.62 \\
\hline MT & 7.25 & 59.55 & 20.37 & 7.16 & 31.96 & 51.41 \\
\hline $\mathrm{NC}$ & -9.53 & -69.41 & -23.14 & -7.93 & -20.89 & -23.76 \\
\hline ND & 42.22 & 336.14 & 32123.90 & 80.20 & -- & 200.10 \\
\hline $\mathrm{NE}$ & -5.13 & -32.96 & -13.77 & -4.76 & -14.27 & -12.40 \\
\hline $\mathrm{NH}$ & 14.70 & 200.40 & 27.86 & 15.69 & 455.65 & 56.60 \\
\hline NJ & -6.47 & -43.51 & -16.04 & -5.24 & -15.47 & -12.32 \\
\hline NM & 13.48 & 96.51 & 33.41 & 14.29 & 73.29 & 30.49 \\
\hline NV & -4.53 & -33.50 & -13.73 & -4.21 & -- & -4.76 \\
\hline NY & 12.92 & 147.67 & 22.19 & 12.92 & 29.13 & 46.87 \\
\hline $\mathrm{OH}$ & 10.73 & 87.59 & 21.96 & 10.24 & 28.82 & 24.09 \\
\hline OK & -2.92 & -18.79 & -7.41 & -2.45 & -7.68 & -7.74 \\
\hline OR & 16.25 & 147.92 & 36.21 & 15.71 & 29.67 & 169.97 \\
\hline PA & 9.17 & 71.13 & 23.58 & 8.93 & 32.66 & 21.05 \\
\hline RI & 1.28 & 11.23 & 3.20 & 1.19 & 4.62 & 3.87 \\
\hline
\end{tabular}




\begin{tabular}{ccccccr}
\hline \hline State & $\begin{array}{c}\text { Total } \\
\text { Expenditures }\end{array}$ & Education & Health & $\begin{array}{c}\text { Total } \\
\text { Receipts }\end{array}$ & $\begin{array}{c}\text { Income } \\
\text { Taxes }\end{array}$ & $\begin{array}{c}\text { Sales } \\
\text { Taxes }\end{array}$ \\
\hline SC & 5.29 & 39.94 & 9.92 & 5.17 & 19.10 & 14.39 \\
SD & 1.32 & 12.45 & 3.27 & 1.23 & -- & 2.45 \\
TN & 4.27 & 32.66 & 8.16 & 4.17 & 271.23 & 7.96 \\
TX & -0.98 & -7.04 & -2.22 & -0.89 & -- & -1.42 \\
UT & -2.12 & -12.74 & -6.75 & -2.00 & -6.18 & -4.95 \\
VA & 0.88 & 5.74 & 2.23 & 0.84 & 1.57 & 2.31 \\
VT & -18.79 & -190.76 & -47.99 & -15.12 & -68.12 & -59.38 \\
WA & 9.29 & 66.09 & 23.17 & 9.58 & -- & 14.58 \\
WI & -9.36 & -66.53 & -20.95 & -7.48 & -14.65 & -15.69 \\
WV & -6.02 & -65.19 & -13.41 & -5.43 & -30.47 & -15.99 \\
WY & 20.46 & 209.10 & 66.47 & 23.35 & -- & 60.75 \\
\hline \hline
\end{tabular}

* State without individual income taxation. 
Table 6 State Intertemporal Budget Imbalances in 1990 and 1999

(measured as a percentage of the present values of expenditures and receipts)

\begin{tabular}{|c|c|c|c|c|c|c|}
\hline \multirow[b]{2}{*}{ State } & \multicolumn{3}{|c|}{1990} & \multicolumn{3}{|c|}{1999} \\
\hline & $\begin{array}{c}\text { Percent of } \\
\text { PV of } \\
\text { Expenditures }\end{array}$ & $\begin{array}{l}\text { Percent of } \\
\text { PV of } \\
\text { Receipts }\end{array}$ & $\begin{array}{c}\text { Rank } \\
\text { Based on } \\
\text { Percent of } \\
\text { PV of } \\
\text { Expenditures } \\
\end{array}$ & $\begin{array}{c}\text { Percent of } \\
\text { PV of } \\
\text { Expenditures }\end{array}$ & $\begin{array}{l}\text { Percent } \\
\text { of PV of } \\
\text { Receipts }\end{array}$ & $\begin{array}{c}\text { Rank } \\
\text { Based on } \\
\text { Percent of } \\
\text { PV of } \\
\text { Expenditures } \\
\end{array}$ \\
\hline $\mathrm{AK}$ & 47.58 & 74.30 & 50 & 48.12 & 77.24 & 50 \\
\hline $\mathrm{AL}$ & 10.63 & 10.38 & 40 & 10.22 & 9.95 & 40 \\
\hline $\mathrm{AR}$ & -4.95 & -4.44 & 9 & -6.49 & -5.79 & 8 \\
\hline $\mathrm{AZ}$ & 6.67 & 6.39 & 30 & 4.77 & 4.55 & 30 \\
\hline $\mathrm{CA}$ & 13.72 & 14.33 & 44 & 12.96 & 13.56 & 43 \\
\hline $\mathrm{CO}$ & 12.73 & 12.77 & 43 & 13.48 & 13.59 & 44 \\
\hline $\mathrm{CT}$ & -8.26 & -6.78 & 3 & -9.99 & -8.10 & 3 \\
\hline $\mathrm{DE}$ & -6.50 & -5.53 & 6 & -7.94 & -6.75 & 6 \\
\hline FL & 3.91 & 3.98 & 26 & 2.58 & 2.62 & 27 \\
\hline GA & 0.00 & 0.00 & 19 & -1.28 & -1.15 & 19 \\
\hline HI & 8.72 & 8.53 & 34 & 8.63 & 8.44 & 36 \\
\hline IA & 9.79 & 10.00 & 37 & 7.96 & 8.11 & 33 \\
\hline ID & -4.23 & -3.84 & 10 & -5.32 & -4.82 & 11 \\
\hline IL & 1.89 & 1.77 & 22 & 0.96 & 0.90 & 24 \\
\hline IN & 1.54 & 1.43 & 21 & 0.68 & 0.63 & 22 \\
\hline $\mathrm{KS}$ & 8.17 & 7.81 & 33 & 8.41 & 8.03 & 35 \\
\hline KY & -0.04 & -0.04 & 18 & -1.29 & -1.18 & 18 \\
\hline LA & 6.76 & 6.03 & 31 & 3.02 & 2.66 & 28 \\
\hline MA & 9.66 & 9.87 & 36 & 9.56 & 9.80 & 39 \\
\hline MD & 8.93 & 8.65 & 35 & 8.32 & 8.06 & 34 \\
\hline ME & -2.64 & -2.31 & 15 & -4.59 & -4.00 & 13 \\
\hline MI & -9.13 & -7.49 & 2 & -11.95 & -9.65 & 2 \\
\hline $\mathrm{MN}$ & 2.17 & 1.97 & 23 & 0.27 & 0.24 & 21 \\
\hline MO & -5.61 & -5.09 & 7 & -7.00 & -6.34 & 7 \\
\hline MS & -3.41 & -3.09 & 13 & -4.35 & -3.94 & 15 \\
\hline MT & 7.15 & 7.08 & 32 & 7.25 & 7.16 & 32 \\
\hline $\mathrm{NC}$ & -6.58 & -5.53 & 5 & -9.53 & -7.93 & 4 \\
\hline ND & 42.05 & 78.52 & 49 & 42.22 & 80.20 & 49 \\
\hline $\mathrm{NE}$ & -4.05 & -3.78 & 11 & -5.13 & -4.76 & 12 \\
\hline $\mathrm{NH}$ & 14.93 & 15.94 & 46 & 14.70 & 15.69 & 46 \\
\hline $\mathrm{NJ}$ & -3.73 & -3.08 & 12 & -6.47 & -5.24 & 9 \\
\hline NM & 14.16 & 15.07 & 45 & 13.48 & 14.29 & 45 \\
\hline $\mathrm{NV}$ & -2.94 & -2.74 & 14 & -4.53 & -4.21 & 14 \\
\hline NY & 12.68 & 12.64 & 42 & 12.92 & 12.92 & 42 \\
\hline $\mathrm{OH}$ & 11.97 & 11.47 & 41 & 10.73 & 10.24 & 41 \\
\hline OK & -1.36 & -1.15 & 16 & -2.92 & -2.45 & 16 \\
\hline OR & 16.63 & 16.06 & 47 & 16.25 & 15.71 & 47 \\
\hline PA & 10.40 & 10.13 & 38 & 9.17 & 8.93 & 37 \\
\hline
\end{tabular}




\begin{tabular}{ccccccc}
\hline \hline State & $\begin{array}{c}\text { Total } \\
\text { Expenditures }\end{array}$ & $\begin{array}{c}\text { Total } \\
\text { Receipts }\end{array}$ & $\begin{array}{c}\text { Rank } \\
\text { (Total Exp.) }\end{array}$ & $\begin{array}{c}\text { Total } \\
\text { Expenditures }\end{array}$ & $\begin{array}{c}\text { Total } \\
\text { Receipts }\end{array}$ & $\begin{array}{c}\text { Rank } \\
\text { (Total Exp.) }\end{array}$ \\
\hline RI & 3.61 & 3.40 & 25 & 1.28 & 1.19 & 25 \\
SC & 6.60 & 6.48 & 29 & 5.29 & 5.17 & 31 \\
SD & 4.36 & 4.12 & 27 & 1.32 & 1.23 & 26 \\
TN & 4.86 & 4.76 & 28 & 4.27 & 4.17 & 29 \\
TX & 1.09 & 0.99 & 20 & -0.98 & -0.89 & 20 \\
UT & -0.99 & -0.94 & 17 & -2.12 & -2.00 & 17 \\
VA & 2.48 & 2.36 & 24 & 0.88 & 0.84 & 23 \\
VT & -16.38 & -13.41 & 1 & -18.79 & -15.12 & 1 \\
WA & 10.46 & 10.80 & 39 & 9.29 & 9.58 & 38 \\
WI & -7.07 & -5.71 & 4 & -9.36 & -7.48 & 5 \\
WV & -5.43 & -4.93 & 8 & -6.02 & -5.43 & 10 \\
WY & 21.08 & 24.10 & 48 & 20.46 & 23.35 & 48 \\
\hline \hline
\end{tabular}


Table 7

Percentage Cuts in the PV of Spending Needed for Present Value Budget Balance

\begin{tabular}{|c|c|c|c|c|c|c|}
\hline State & $\begin{array}{l}\text { Baseline } \\
\text { Case }\end{array}$ & $\begin{array}{c}1 \% \\
\text { Productivity }\end{array}$ & $\begin{array}{c}2 \% \\
\text { Productivity }\end{array}$ & $\begin{array}{c}\mathbf{2 \%} \\
\text { Discount } \\
\text { Rate }\end{array}$ & $\begin{array}{c}\mathbf{4 \%} \\
\text { Discount } \\
\text { Rate }\end{array}$ & $\begin{array}{c}\text { Ten-Year } \\
\text { Growth in } \\
\text { Population } \\
\text { Shares } \\
\end{array}$ \\
\hline $\mathrm{AK}$ & 48.12 & 47.16 & 49.10 & 50.11 & 46.26 & 47.92 \\
\hline $\mathrm{AL}$ & 10.22 & 9.05 & 11.45 & 12.74 & 7.97 & 10.15 \\
\hline AR & -6.49 & -7.26 & -5.64 & -4.68 & -7.94 & -6.60 \\
\hline $\mathrm{AZ}$ & 4.77 & 3.20 & 6.38 & 8.03 & 1.70 & 4.97 \\
\hline $\mathrm{CA}$ & 12.96 & 10.95 & 15.08 & 17.34 & 9.10 & 13.07 \\
\hline $\mathrm{CO}$ & 13.48 & 11.25 & 15.92 & 18.62 & 9.29 & 13.80 \\
\hline $\mathrm{CT}$ & -9.99 & -10.68 & -9.10 & -7.97 & -11.21 & -10.20 \\
\hline $\mathrm{DE}$ & -7.94 & -9.27 & -6.39 & -4.60 & -10.39 & -8.12 \\
\hline FL & 2.58 & 0.80 & 4.52 & 6.65 & -0.79 & 2.53 \\
\hline GA & -1.28 & -2.09 & -0.39 & 0.62 & -2.81 & -1.31 \\
\hline $\mathrm{HI}$ & 8.63 & 7.81 & 9.55 & 10.60 & 7.10 & 8.43 \\
\hline IA & 7.96 & 6.24 & 9.75 & 11.63 & 4.63 & 7.75 \\
\hline ID & -5.32 & -6.54 & -3.98 & -2.49 & -7.62 & -5.14 \\
\hline IL & 0.96 & -0.68 & 2.83 & 4.94 & -2.09 & 0.80 \\
\hline IN & 0.68 & 0.02 & 1.46 & 2.39 & -0.53 & 0.54 \\
\hline $\mathrm{KS}$ & 8.41 & 7.83 & 9.03 & 9.71 & 7.31 & 8.08 \\
\hline KY & -1.29 & -2.73 & 0.30 & 2.05 & -4.00 & -1.25 \\
\hline LA & 3.02 & 1.96 & 4.08 & 5.15 & 0.94 & 2.85 \\
\hline MA & 9.56 & 8.59 & 10.81 & 12.39 & 7.88 & 9.53 \\
\hline MD & 8.32 & 6.66 & 10.13 & 12.12 & 5.18 & 8.26 \\
\hline ME & -4.59 & -6.36 & -2.59 & -0.35 & -7.88 & -4.83 \\
\hline MI & -11.95 & -13.18 & -10.61 & -9.15 & -14.29 & -12.24 \\
\hline $\mathrm{MN}$ & 0.27 & -2.31 & 3.04 & 6.04 & -4.63 & 0.19 \\
\hline MO & -7.00 & -8.14 & -5.75 & -4.39 & -9.16 & -7.27 \\
\hline MS & -4.35 & -5.13 & -3.52 & -2.60 & -5.82 & -4.43 \\
\hline MT & 7.25 & 6.62 & 7.96 & 8.77 & 6.09 & 7.30 \\
\hline $\mathrm{NC}$ & -9.53 & -10.80 & -8.29 & -7.05 & -12.04 & -9.60 \\
\hline ND & 42.22 & 39.95 & 44.70 & 47.39 & 37.92 & 42.10 \\
\hline $\mathrm{NE}$ & -5.13 & -5.59 & -4.57 & -3.88 & -5.96 & -5.24 \\
\hline $\mathrm{NH}$ & 14.70 & 13.78 & 15.83 & 17.21 & 13.07 & 14.68 \\
\hline $\mathrm{NJ}$ & -6.47 & -7.87 & -4.94 & -3.25 & -9.12 & -6.62 \\
\hline NM & 13.48 & 12.97 & 13.99 & 14.51 & 12.49 & 13.45 \\
\hline NV & -4.53 & -6.08 & -2.87 & -1.05 & -7.48 & -4.20 \\
\hline NY & 12.92 & 12.07 & 13.87 & 14.94 & 11.34 & 12.91 \\
\hline $\mathrm{OH}$ & 10.73 & 8.08 & 13.52 & 16.43 & 5.63 & 10.45 \\
\hline OK & -2.92 & -3.69 & -2.07 & -1.14 & -4.38 & -3.09 \\
\hline OR & 16.25 & 14.34 & 18.30 & 20.48 & 12.60 & 16.39 \\
\hline PA & 9.17 & 6.89 & 11.63 & 14.30 & 4.86 & 8.78 \\
\hline RI & 1.28 & 0.28 & 2.44 & 3.80 & -0.55 & 1.28 \\
\hline $\mathrm{SC}$ & 5.29 & 4.24 & 6.45 & 7.71 & 3.32 & 5.35 \\
\hline
\end{tabular}




\begin{tabular}{ccccccc}
\hline \hline State & $\begin{array}{c}\text { Baseline } \\
\text { Case }\end{array}$ & $\begin{array}{c}\mathbf{1 \%} \\
\text { Productivity }\end{array}$ & $\begin{array}{c}\mathbf{2 \%} \\
\text { Productivity }\end{array}$ & $\begin{array}{c}\mathbf{2 \%} \\
\text { Discount } \\
\text { Rate }\end{array}$ & $\begin{array}{c}\mathbf{4 \%} \\
\text { Discount } \\
\text { Rate }\end{array}$ & $\begin{array}{c}\text { Ten-Year } \\
\text { Growth in } \\
\text { Population } \\
\text { Shares }\end{array}$ \\
\hline SD & 1.32 & -0.10 & 2.83 & 4.46 & -1.39 & 1.21 \\
TN & 4.27 & 3.44 & 5.18 & 6.17 & 2.70 & 4.24 \\
TX & -0.98 & -2.57 & 0.63 & 2.27 & -4.08 & -0.93 \\
UT & -2.12 & -3.24 & -0.85 & 0.61 & -4.20 & -1.92 \\
VA & 0.88 & -0.58 & 2.47 & 4.21 & -1.89 & 0.87 \\
VT & -18.79 & -19.57 & -17.79 & -16.54 & -20.15 & -18.97 \\
WA & 9.29 & 7.23 & 11.49 & 13.82 & 5.35 & 9.54 \\
WI & -9.36 & -12.18 & -6.43 & -3.39 & -14.81 & -9.61 \\
WV & -6.02 & -6.40 & -5.45 & -4.64 & -6.61 & -5.95 \\
WY & 20.46 & 19.55 & 21.40 & 22.39 & 18.69 & 20.35 \\
\hline \hline
\end{tabular}


Table 8

Percentage Increases in PV of Receipts Needed for Present Value Budget Balance

\begin{tabular}{|c|c|c|c|c|c|c|}
\hline State & $\begin{array}{l}\text { Baseline } \\
\text { Case }\end{array}$ & $\begin{array}{c}1 \% \\
\text { Productivity }\end{array}$ & $\begin{array}{c}2 \% \\
\text { Productivity }\end{array}$ & $\begin{array}{c}2 \% \\
\text { Discount } \\
\text { Rate }\end{array}$ & $\begin{array}{c}4 \% \\
\text { Discount } \\
\text { Rate }\end{array}$ & $\begin{array}{c}\text { Ten-Year } \\
\text { Growth in } \\
\text { Population } \\
\text { Shares }\end{array}$ \\
\hline $\mathrm{AK}$ & 77.24 & 75.47 & 79.09 & 81.03 & 73.82 & 76.98 \\
\hline $\mathrm{AL}$ & 9.95 & 8.81 & 11.16 & 12.45 & 7.76 & 9.85 \\
\hline $\mathrm{AR}$ & -5.79 & -6.49 & -5.03 & -4.18 & -7.11 & -5.88 \\
\hline $\mathrm{AZ}$ & 4.55 & 3.06 & 6.08 & 7.65 & 1.63 & 4.75 \\
\hline CA & 13.56 & 11.38 & 15.91 & 18.48 & 9.42 & 13.69 \\
\hline $\mathrm{CO}$ & 13.59 & 11.24 & 16.23 & 19.26 & 9.22 & 13.97 \\
\hline $\mathrm{CT}$ & -8.10 & -8.63 & -7.42 & -6.54 & -9.03 & -8.26 \\
\hline $\mathrm{DE}$ & -6.75 & -7.84 & -5.48 & -3.98 & -8.75 & -6.89 \\
\hline FL & 2.62 & 0.81 & 4.63 & 6.88 & -0.80 & 2.57 \\
\hline GA & -1.15 & -1.88 & -0.35 & 0.56 & -2.52 & -1.17 \\
\hline HI & 8.44 & 7.61 & 9.38 & 10.47 & 6.90 & 8.24 \\
\hline IA & 8.11 & 6.36 & 9.94 & 11.88 & 4.73 & 7.89 \\
\hline ID & -4.82 & -5.92 & -3.61 & -2.26 & -6.90 & -4.66 \\
\hline IL & 0.90 & -0.63 & 2.67 & 4.72 & -1.93 & 0.75 \\
\hline IN & 0.63 & 0.02 & 1.35 & 2.21 & -0.49 & 0.50 \\
\hline $\mathrm{KS}$ & 8.03 & 7.52 & 8.59 & 9.22 & 7.05 & 7.69 \\
\hline KY & -1.18 & -2.51 & 0.28 & 1.90 & -3.67 & -1.15 \\
\hline LA & 2.66 & 1.73 & 3.60 & 4.54 & 0.83 & 2.52 \\
\hline MA & 9.80 & 8.72 & 11.22 & 13.07 & 7.93 & 9.76 \\
\hline MD & 8.06 & 6.41 & 9.91 & 11.99 & 4.97 & 8.01 \\
\hline ME & -4.00 & -5.49 & -2.28 & -0.31 & -6.77 & -4.19 \\
\hline MI & -9.65 & -10.65 & -8.56 & -7.39 & -11.58 & -9.87 \\
\hline MN & 0.24 & -2.07 & 2.77 & 5.57 & -4.14 & 0.17 \\
\hline MO & -6.34 & -7.37 & -5.21 & -3.99 & -8.31 & -6.57 \\
\hline MS & -3.94 & -4.65 & -3.17 & -2.33 & -5.30 & -4.00 \\
\hline MT & 7.16 & 6.54 & 7.86 & 8.67 & 6.02 & 7.22 \\
\hline $\mathrm{NC}$ & -7.93 & -9.03 & -6.85 & -5.81 & -10.12 & -7.96 \\
\hline ND & 80.20 & 74.26 & 87.17 & 95.45 & 69.29 & 79.81 \\
\hline $\mathrm{NE}$ & -4.76 & -5.19 & -4.24 & -3.60 & -5.53 & -4.86 \\
\hline $\mathrm{NH}$ & 15.69 & 14.57 & 17.11 & 18.86 & 13.71 & 15.64 \\
\hline $\mathrm{NJ}$ & -5.24 & -6.37 & -4.01 & -2.65 & -7.39 & -5.37 \\
\hline NM & 14.29 & 13.82 & 14.78 & 15.27 & 13.35 & 14.27 \\
\hline NV & -4.21 & -5.66 & -2.66 & -0.98 & -6.97 & -3.91 \\
\hline NY & 12.92 & 12.03 & 13.94 & 15.12 & 11.26 & 12.92 \\
\hline $\mathrm{OH}$ & 10.24 & 7.69 & 12.94 & 15.82 & 5.35 & 9.96 \\
\hline OK & -2.45 & -3.10 & -1.74 & -0.95 & -3.69 & -2.60 \\
\hline OR & 15.71 & 13.77 & 17.82 & 20.14 & 12.05 & 15.87 \\
\hline $\mathrm{PA}$ & 8.93 & 6.67 & 11.43 & 14.22 & 4.68 & 8.53 \\
\hline RI & 1.19 & 0.26 & 2.29 & 3.58 & -0.51 & 1.18 \\
\hline $\mathrm{SC}$ & 5.17 & 4.14 & 6.31 & 7.59 & 3.23 & 5.21 \\
\hline
\end{tabular}




\begin{tabular}{ccccccc}
\hline \hline State & $\begin{array}{c}\text { Baseline } \\
\text { Case }\end{array}$ & $\begin{array}{c}\mathbf{1 \%} \\
\text { Productivity }\end{array}$ & $\begin{array}{c}\mathbf{2 \%} \\
\text { Productivity }\end{array}$ & $\begin{array}{c}\mathbf{2 \%} \\
\text { Discount } \\
\text { Rate }\end{array}$ & $\begin{array}{c}\mathbf{4 \%} \\
\text { Discount } \\
\text { Rate }\end{array}$ & $\begin{array}{c}\text { Ten-Year } \\
\text { Growth in } \\
\text { Population } \\
\text { Shares }\end{array}$ \\
\hline SD & 1.23 & -0.10 & 2.66 & 4.21 & -1.30 & 1.13 \\
TN & 4.17 & 3.36 & 5.07 & 6.07 & 2.63 & 4.14 \\
TX & -0.89 & -2.32 & 0.57 & 2.06 & -3.69 & -0.84 \\
UT & -2.00 & -3.05 & -0.81 & 0.58 & -3.96 & -1.81 \\
VA & 0.84 & -0.55 & 2.35 & 4.02 & -1.79 & 0.83 \\
VT & -15.12 & -15.69 & -14.41 & -13.51 & -16.11 & -15.25 \\
WA & 9.58 & 7.40 & 11.95 & 14.55 & 5.45 & 9.86 \\
WI & -7.48 & -9.75 & -5.14 & -2.72 & -11.88 & -7.67 \\
WV & -5.43 & -5.76 & -4.94 & -4.24 & -5.94 & -5.38 \\
WY & 23.35 & 22.33 & 24.42 & 25.54 & 21.37 & 23.21 \\
\hline \hline
\end{tabular}


Table 9

1999 State General Obligation Bond Ratings

\begin{tabular}{|c|c|c|c|c|}
\hline State & $\begin{array}{c}\text { Moody's } \\
\text { G. O. Rating }\end{array}$ & $\begin{array}{l}\text { S\&P's } \\
\text { G. O. Rating }\end{array}$ & $\begin{array}{c}\text { Imbalance } \\
\text { Measured } \\
\text { Relative to the } \\
\text { PV of Spending }\end{array}$ & $\begin{array}{c}\text { Imbalance } \\
\text { Measured } \\
\text { Relative to the } \\
\text { PV of Receipts }\end{array}$ \\
\hline AK & $\mathrm{Aa} 2$ & AA & 48.12 & 77.24 \\
\hline $\mathrm{AL}$ & $\mathrm{Aa} 3$ & AA & 10.22 & 9.95 \\
\hline AR & $\mathrm{Aa} 3$ & AA & -6.49 & -5.79 \\
\hline $\mathrm{AZ}$ & $--*$ & $--*$ & 4.77 & 4.55 \\
\hline CA & $\mathrm{Aa} 3$ & AA- & 12.96 & 13.56 \\
\hline $\mathrm{CO}$ & -- & -- & 13.48 & 13.59 \\
\hline $\mathrm{CT}$ & $\mathrm{Aa} 3$ & AA & -9.99 & -8.10 \\
\hline $\mathrm{DE}$ & Aal & $\mathrm{AA}+$ & -7.94 & -6.75 \\
\hline FL & $\mathrm{Aa} 2$ & $\mathrm{AA}+$ & 2.58 & 2.62 \\
\hline GA & Aaа & AAA & -1.28 & -1.15 \\
\hline HI & $\mathrm{A} 1$ & $\mathrm{~A}^{+}$ & 8.63 & 8.44 \\
\hline IA & -- & -- & 7.96 & 8.11 \\
\hline ID & -- & -- & -5.32 & -4.82 \\
\hline IL & $\mathrm{Aa} 2$ & $\mathrm{AA}$ & 0.96 & 0.90 \\
\hline IN & Aal & $\mathrm{AA}+$ & 0.68 & 0.63 \\
\hline $\mathrm{KS}$ & -- & $\mathrm{AA}+$ & 8.41 & 8.03 \\
\hline KY & $\mathrm{Aa} 2$ & $\mathrm{AA}$ & -1.29 & -1.18 \\
\hline LA & $\mathrm{A} 2$ & A- & 3.02 & 2.66 \\
\hline MA & $\mathrm{Aa} 3$ & AA- & 9.56 & 9.80 \\
\hline MD & Aaa & $\mathrm{AAA}$ & 8.32 & 8.06 \\
\hline ME & $\mathrm{Aa} 2$ & $\mathrm{AA}^{+}$ & -4.59 & -4.00 \\
\hline MI & Aal & $\mathrm{AA}^{+}$ & -11.95 & -9.65 \\
\hline $\mathrm{MN}$ & Aaа & AAA & 0.27 & 0.24 \\
\hline MO & Aaа & $\mathrm{AAA}$ & -7.00 & -6.34 \\
\hline MS & $\mathrm{Aa} 3$ & $\mathrm{AA}$ & -4.35 & -3.94 \\
\hline MT & $\mathrm{Aa} 3$ & AA- & 7.25 & 7.16 \\
\hline $\mathrm{NC}$ & Aaa & AAA & -9.53 & -7.93 \\
\hline ND & -- & AA- & 42.22 & 80.20 \\
\hline $\mathrm{NE}$ & -- & -- & -5.13 & -4.76 \\
\hline $\mathrm{NH}$ & $\mathrm{Aa} 2$ & $\mathrm{AA}+$ & 14.70 & 15.69 \\
\hline $\mathrm{NJ}$ & Aal & $\mathrm{AA}+$ & -6.47 & -5.24 \\
\hline NM & Aal & $\mathrm{AA}+$ & 13.48 & 14.29 \\
\hline NV & $\mathrm{Aa} 2$ & $\mathrm{AA}$ & -4.53 & -4.21 \\
\hline NY & $\mathrm{A} 2$ & $\mathrm{~A}^{+}$ & 12.92 & 12.92 \\
\hline $\mathrm{OH}$ & Aal & $\mathrm{AA}+$ & 10.73 & 10.24 \\
\hline OK & $\mathrm{Aa} 3$ & $\mathrm{AA}$ & -2.92 & -2.45 \\
\hline OR & $\mathrm{Aa} 2$ & AA & 16.25 & 15.71 \\
\hline $\mathrm{PA}$ & $\mathrm{Aa} 3$ & $\mathrm{AA}$ & 9.17 & 8.93 \\
\hline RI & $\mathrm{Aa} 3$ & AA- & 1.28 & 1.19 \\
\hline $\mathrm{SC}$ & Aaa & AAA & 5.29 & 5.17 \\
\hline
\end{tabular}




\begin{tabular}{cllcc}
\hline \hline State & $\begin{array}{c}\text { Moody's } \\
\text { G. O. Rating }\end{array}$ & $\begin{array}{c}\text { S\&P's } \\
\text { G. O. Rating }\end{array}$ & $\begin{array}{c}\text { Imbalance } \\
\text { Measured } \\
\text { Relative to the } \\
\text { PV of Spending }\end{array}$ & $\begin{array}{c}\text { Imbalance } \\
\text { Measured } \\
\text { Relative to the } \\
\text { PV of Receipts }\end{array}$ \\
\hline SD & -- & -- & 1.32 & 1.23 \\
TN & Aaa & AAA & 4.27 & 4.17 \\
TX & Aa1 & AA & -0.98 & -0.89 \\
UT & Aaa & AAA & -2.12 & -2.00 \\
VA & Aaa & AAA & 0.88 & 0.84 \\
VT & Aa1 & AA & -18.79 & -15.12 \\
WA & Aa1 & AA+ & 9.29 & 9.58 \\
WI & Aa2 & AA & -9.36 & -7.48 \\
WV & Aa3 & AA- & -6.02 & -5.43 \\
WY & -- & AA & 20.46 & 23.35 \\
\hline \hline
\end{tabular}

* State was not ranked by the respective agency in 1999 
Table 10

1990 State General Obligation Bond Ratings

\begin{tabular}{|c|c|c|c|c|}
\hline State & $\begin{array}{l}\text { Moody's } \\
\text { G. O. Rating }\end{array}$ & $\begin{array}{l}\text { S\&P's } \\
\text { G. O. Rating }\end{array}$ & $\begin{array}{l}\text { Imbalance } \\
\text { Measured } \\
\text { Relative to the } \\
\text { PV of Spending }\end{array}$ & $\begin{array}{c}\text { Imbalance } \\
\text { Measured } \\
\text { Relative to the } \\
\text { PV of Receipts }\end{array}$ \\
\hline AK & $\mathrm{Aa}$ & AA- & 47.58 & 74.30 \\
\hline $\mathrm{AL}$ & $\mathrm{Aa}$ & $\mathrm{AA}$ & 10.63 & 10.38 \\
\hline AR & $\mathrm{Aa}$ & AA & -4.95 & -4.44 \\
\hline $\mathrm{AZ}$ & $--*$ & -- & 6.67 & 6.39 \\
\hline $\mathrm{CA}$ & Aaa & $\mathrm{AAA}$ & 13.72 & 14.33 \\
\hline $\mathrm{CO}$ & -- & -- & 12.73 & 12.77 \\
\hline $\mathrm{CT}$ & $\mathrm{Aa}$ & $\mathrm{AA}$ & -8.26 & -6.78 \\
\hline $\mathrm{DE}$ & $\mathrm{Aa}$ & $\mathrm{AA}^{+}$ & -6.50 & -5.53 \\
\hline FL & $\mathrm{Aa}$ & $\mathrm{AA}$ & 3.91 & 3.98 \\
\hline GA & Aaа & $\mathrm{AA}+$ & 0.00 & 0.00 \\
\hline HI & $\mathrm{Aa}$ & $\mathrm{AA}$ & 8.72 & 8.53 \\
\hline IA & -- & -- & 9.79 & 10.00 \\
\hline ID & -- & -- & -4.23 & -3.84 \\
\hline IL & Aaa & $\mathrm{AA}+$ & 1.89 & 1.77 \\
\hline IN & -- & -- & 1.54 & 1.43 \\
\hline $\mathrm{KS}$ & -- & -- & 8.17 & 7.81 \\
\hline KY & -- & -- & -0.04 & -0.04 \\
\hline LA & Baal & A & 6.76 & 6.03 \\
\hline MA & Baa & BBB & 9.66 & 9.87 \\
\hline MD & Aaa & $\mathrm{AAA}$ & 8.93 & 8.65 \\
\hline ME & Aal & AAA & -2.64 & -2.31 \\
\hline MI & $\mathrm{A} 1$ & $\mathrm{AA}$ & -9.13 & -7.49 \\
\hline MN & $\mathrm{Aa}$ & $\mathrm{AA}+$ & 2.17 & 1.97 \\
\hline MO & Aaа & $\mathrm{AAA}$ & -5.61 & -5.09 \\
\hline MS & $\mathrm{Aa}$ & AA- & -3.41 & -3.09 \\
\hline MT & $\mathrm{Aa}$ & AA- & 7.15 & 7.08 \\
\hline $\mathrm{NC}$ & Aaa & $\mathrm{AAA}$ & -6.58 & -5.53 \\
\hline ND & -- & -- & 42.05 & 78.52 \\
\hline $\mathrm{NE}$ & -- & -- & -4.05 & -3.78 \\
\hline $\mathrm{NH}$ & Aal & $\mathrm{AA}^{+}$ & 14.93 & 15.94 \\
\hline $\mathrm{NJ}$ & Aaа & $\mathrm{AAA}$ & -3.73 & -3.08 \\
\hline NM & $\mathrm{Aa}$ & $\mathrm{AA}$ & 14.16 & 15.07 \\
\hline NV & $\mathrm{Aa}$ & AA & -2.94 & -2.74 \\
\hline NY & A & A & 12.68 & 12.64 \\
\hline $\mathrm{OH}$ & $\mathrm{Aa}$ & AA & 11.97 & 11.47 \\
\hline OK & $\mathrm{Aa}$ & $\mathrm{AA}$ & -1.36 & -1.15 \\
\hline OR & $\mathrm{Aa}$ & AA- & 16.63 & 16.06 \\
\hline $\mathrm{PA}$ & $\mathrm{A} 1$ & AA- & 10.40 & 10.13 \\
\hline RI & $\mathrm{Aa}$ & -- & 3.61 & 3.40 \\
\hline $\mathrm{SC}$ & Aaa & AAA & 6.60 & 6.48 \\
\hline
\end{tabular}




\begin{tabular}{cllcc}
\hline \hline State & $\begin{array}{c}\text { Moody's } \\
\text { G. O. Rating }\end{array}$ & $\begin{array}{c}\text { S\&P's } \\
\text { G. O. Rating }\end{array}$ & $\begin{array}{c}\text { Imbalance } \\
\text { Measured } \\
\text { Relative to the } \\
\text { PV of Spending }\end{array}$ & $\begin{array}{c}\text { Imbalance } \\
\text { Measured } \\
\text { Relative to the } \\
\text { PV of Receipts }\end{array}$ \\
\hline SD & -- & -- & 4.36 & 4.12 \\
TN & Aaa & AA+ & 4.86 & 4.76 \\
TX & Aa & AA & 1.09 & 0.99 \\
UT & Aaa & AAA & -0.99 & -0.94 \\
VA & Aaa & AAA & 2.48 & 2.36 \\
VT & Aa & AA & -16.38 & -13.41 \\
WA & Aa & AA & 10.46 & 10.80 \\
WI & Aa & AA & -7.07 & -5.71 \\
WV & A1 & A+ & -5.43 & -4.93 \\
WY & -- & -- & 21.08 & 24.10 \\
\hline \hline
\end{tabular}

* State was not ranked by the respective agency in 1990 